\title{
Educational (Mis)match and skill utilization in Germany: Assessing the role of worker and job characteristics
}

\author{
Daniela Rohrbach-Schmidt $\cdot$ Michael Tiemann
}

Published online: 17 February 2016

(C) The Author(s) 2016. This article is published with open access at Springerlink.com

\begin{abstract}
This paper provides precise figures on the incidence and wage penalties of mismatching in Germany. We use the BIBB/BAuA Employment Survey 2006 to compute two different measures of person-to-job matching. A first measure indicates an educational (mis)match, i.e., whether a worker's attained level of education corresponds to the qualificational requirements of his or her job. Second, and different from most other studies - we observe a skill (mis)match that reflects the correspondence between the skills of the job holder and the skill requirements of the job. We explore whether and the extent to which results on mismatch differ between these measures and explain the probability of being (mis)matched by different sets of worker and job characteristics. We also examine wage penalties for mismatching in Germany, considering a large number of controls for workers and, in addition to most earlier studies, job heterogeneity; we use random intercept models with workers nested in occupations. Our results indicate that large shares of over- or under-educated workers in Germany have skills that correspond to the skill requirements of their jobs. Furthermore, there are workers perfectly matched with respect to their education who, nevertheless, feel under- or over-challenged by their jobs' skill requirements. Random intercept models reveal that beyond
\end{abstract}

D. Rohrbach-Schmidt $(\bowtie) \cdot$ M. Tiemann

Department of Sociology and Economics of Vocational Education and Training, Federal Institute for Vocational Education and Training,

Robert-Schuman Platz 3,

53175 Bonn, Germany

e-mail: rohrbach@bibb.de

M. Tiemann

e-mail: tiemann@bibb.de worker characteristics, i.e., human capital compensation (heterogeneous ability) and career mobility rationalities, job characteristics play a role in the mismatching variance and its real or apparent wage penalties.

Keywords Mismatch - Skill utilization - Overeducation · Job skills · Labor supply and demand - Wage penalties

\section{Qualifikatorisches (Mis)matching und die Ausnutzung von fachlichen Kenntnissen und Fähigkeiten von Erwerbstätigen in Deutschland: Zur Bedeutung von Personen- und Arbeitsplatzmerkmalen}

Zusammenfassung Der Artikel bietet detaillierte Ergebnisse zur Inzidenz und zu den Lohneinbußen von fehlqualifizierter Beschäftigung in Deutschland. Wir nutzen die BIBB/BAuA-Erwerbstätigenbefragung 2006, um zwei verschiedene Maße des Matchings zwischen Erwerbstätigen und ihren Arbeitsplätzen zu berechnen. Ein erstes Maß zeigt eine formale Fehlqualifizierung an und beinhaltet, inwieweit das Niveau des erreichten beruflichen Bildungsabschlusses mit der qualifikatorischen Anforderung des Arbeitsplatzes übereinstimmt. Zweitens - und anders als die meisten anderen Studien - betrachten wir fähigkeitsbezogenes Mismatching, das die Entsprechung zwischen den fachlichen Kenntnissen und Fähigkeiten der Erwerbstätigen mit den Anforderungen des Arbeitsplatzes an diese widerspiegelt. Wir untersuchen, ob und inwieweit sich die Befunde zu Mismatching zwischen diesen Maßen unterscheiden und versuchen das Auftreten von Mismatching durch Merkmale der Erwerbstätigen und Arbeitsplätze zu erklären. Wir untersuchen weiterhin die mit fehlqualifizierter Beschäftigung verbundenen Lohneinbußen in Deutschland und berücksichtigen dabei eine große Zahl von Kon- 
trollvariablen auf der Personenebene und - zusätzlich zu den meisten früheren Studien - die Heterogenität zwischen Arbeitsplätzen; wir verwenden Random-Intercept-Modelle mit Erwerbstätigen in Berufen. Unsere Ergebnisse zeigen, dass große Anteile der formal Über- oder Unterqualifizierten in Deutschland fachliche Fähigkeiten und Kenntnisse haben, die zu den Anforderungen des Arbeitsplatzes passen. Gleichzeitig gibt es Erwerbstätige, die formal passend qualifiziert beschäftigt sind, sich aber in Bezug auf ihre fachlichen Kenntnisse und Fähigkeiten unter- oder überfordert fühlen. Random Intercept-Modelle zeigen, dass über Eigenschaften der Erwerbstätigen hinaus, d.h. Humankapital (heterogene Fähigkeiten) und berufliche Aufstiegserwartungen, Arbeitsplatzmerkmale eine Rolle bei fehlqualifizierter Beschäftigung und ihren tatsächlichen oder scheinbaren Lohneinbußen spielen.

\section{JEL Classification I21 $\cdot$ J23 $\cdot$ J24}

\section{Introduction}

Mismatching, i.e., the missing correspondence between the skills of a job-holder and the skill requirements of his job, might have negative consequences for the worker himself (e.g., in the form of wage penalties or job dissatisfaction), for the firm in which he is employed, and for the national economy. As several authors have demonstrated, in most industrialized countries studied - including Germany-substantial fractions of the labor force seem to be over- or underqualified for their jobs. However, to date, there is no current in-depth information on the incidence rates and wage penalties due to educational match and skill utilization in Germany.

Moreover, at least two recent findings justify research in the field. First, some studies see signs of an increase in overeducation in Europe (Korpi and Tåhlin 2009; Green 2006). As an analysis of the BIBB/IAB and BIBB/BAuA Employment Surveys 1979-2006 shows, there seem to be similar trends in Germany as well. The proportion of workers stating that their current job could also be performed by workers with lower qualifications declined from 1979 to $1985 / 1986$ and then increased through 1998/1999 within the population of West German full-time male workers aged 25 to 65 . Similarly, from 1998/99 to 2006, the proportion of workers who state that they generally feel under-challenged by the requirements of their current jobs compared with their skills has doubled from 6 to $12 \%$ (Rohrbach-Schmidt and Tiemann 2011).

Second, studies using the task approach (Autor et al. 2003) have formulated a re-fined version of the skill biased technological change hypothesis and characterized current skill demand trends as polarization.

Germany is a particularly good case for the study of mismatching. First, a central characteristic of the German skill system is its comparatively strong vocational orientation. For most vocational programs at the upper-secondary and tertiary levels, the emphasis lies on learning (occupation-) specific skills as such skills act as clear signaling devices for employees. Consequently, in Germany, access to most occupational positions requires formal certification. Against that background, some argue that the German skill system is not able to adapt the amount and types of skills of their (future) workforce to the altered skill demands (Carnoy 2009). In contrast, others see the close links between the education and the employment systems as ensuring good coordination between skill demand and supply with comparatively low rates for mismatching (Büchel and Witte 1997; Daly et al. 2000). Very recently, Verhaest and Van der Velden (2013), in a cross-national comparative study, find that countries that place high importance on specific orientation experience less overeducation in first jobs.

Second, in Germany, there is a specially designed survey for the study of educational mismatch and skill utilization. The BIBB/BAuA Employment Survey 2006 (Hall and Tiemann 2009; Rohrbach-Schmidt 2009), using a sample size of 20,000 workers, provides for the rare opportunity to study mismatching based on multiple measures of respondents' supply of (in)formal skills and their jobs' skill requirements. While the data in this strand of literature do not allow for encountering the problem of omitted variable bias by fixed effects techniques (e.g., see Leuven and Oosterbeek 2011), in contrast to most earlier studies in Germany, we can control for a large amount of usually unobserved human capital, skill utilization and skill requirement measures.

This paper aims to contribute to the current literature by providing more actual and precise figures on the incidence rates and wage penalties of educational and skill-related mismatching in Germany. First, regarding the correspondence between workers' skills and job requirements, in our analyses we differentiate between educational and skill-related (mis)matching. Given the characteristics of the German skill system and the difficulties in determining and measuring workers' skills and job requirements as such (Handel 2003), it seems valuable to consider the similarities and differences in 'mis-education' and 'mis-skilling'. Second, there is little knowledge on different sub-groups among mismatched workers (Korpi and Tåhlin 2009). Using the large German sample of workers, we examine decisive worker characteristics of education and skill mismatched employees as well as job tasks and changes in skill requirements associated with their jobs. Thus, we link the task approach to the debate on mismatching in Germany. To see first, how much of the probability of being (mis)matched results from differences between occupations and workers, respectively, and second, which worker and job covariates have a share in mismatching, we run a set of logistic random intercept models. Third, we analyze wage penalties for mismatching in Germany, 
considering a large number of controls with respect to the worker and, in addition to most earlier studies, job heterogeneity exploiting random intercept models with workers nested in occupations. In particular, we test a job heterogeneity hypothesis against the human capital compensation hypothesis and, to the extent possible, ${ }^{1}$ the occupational mobility hypothesis for Germany. This paper is organized as follows. We first review available evidence on skill demand and supply (trends) and on mismatching in Germany. This is followed by a theoretical explanation of mismatching. Section 3 describes the data and methods used. In the empirical section, we explore the incidence rates and wage penalties of mismatching in the German labor force using random coefficient models. The paper concludes with a short summary of the results.

\section{Education, skills, and job requirements: theory and evidence}

\subsection{Skill supply, skill demand, and (mis)matching in Germany}

Since the 1970s, there has been a sustained increase in enrollment rates and time spent in the educational system among the OECD population, including Germany (Hadjar and Becker 2009; OECD 2007). The German educational system $^{2}$ is characterized by comparatively high levels of standardization and stratification, and compared with other countries, it is highly vocationally oriented. However, it has shown strong continuity during the second half of the 20th century, providing a stable educational foundation for educational choices (Hillmert 2008, p. 59). Access to most occupational positions requires formal certification from a vocational institution at the upper secondary level (dual-/ school-based system of vocational education) or tertiary level (vocational colleges/academies, universities). A significant portion of the working population, approximately $60 \%$, have a vocational degree from an upper-secondary level institution as their highest degree and most were attained within the dual system, i.e., a (mostly) three-year apprenticeship training with part-time workplace training in firms and in state-provided vocational schools. The dual system provides trainees with occupation-specific skills, grants employers a long screening period, and thus leads to comparatively smooth transitions of labor market entrants (for a

\footnotetext{
${ }^{1}$ Unfortunately, the in-depth matching information we are using is not available on a panel basis. In general, we see that an important contribution to the literature would be to study individual change (e.g., see Hartog 2000).

${ }^{2}$ For a detailed discussion of the German education system and an examination of how the International Standard Classification of Education (ISCED-97) applies to it cf. Schneider (2008).
}

discussion of the advantages of the dual system, see Dustmann and Schoenberg (2008)). Given the high participation rates in the apprenticeship program (and students in schoolbased vocational education programs and advanced training programs in tertiary vocational colleges and academies), with approximately $25 \%$ of the population's respective age groups, tertiary academic graduation is not as common as it is in other industrialized countries (Statistisches Bundesamt 2009, p. 19).

Turning from the supply side to the demand side, the question as to which types of skill requirements are growing versus declining is a controversial topic (Handel 2003, 2008). Predominantly, there is the view that the demand for skills is monotonously rising, that is, the demand is rising for skilled workers and decreasing for unskilled workers (upgrading). This is largely based on the observation that in the 1980s, the US wage growth was monotone in wage percentiles (Acemoglu 2002; Morris and Western 1999). The common explanation for this upgrading trend is the rising computerization of labor due to falling computer prices and it has been termed skill-biased technical change (SBTC). However, in addition to a number of troubling facts related to the classical SBTC theory (Card and DiNardo 2002), the theory might be criticized for evaluating changes in the rewards for skills and changes in the between components of structural change (i.e., an increase in sectors, industries, and occupations) they are rather indirect measures of skills and are not sufficiently informative regarding the skill content of jobs ${ }^{3}$.

In response to the difficulty in capturing skill content using wage returns to education or occupational schemes as such, Autor et al. (2003), hereafter ALM, developed an approach that classifies jobs according to their core task requirements, namely, the main activities workers must perform at work, and relates these task requirements to formal and informal skills that the job-holder must possess to carry out these tasks. This new conceptual framework has been applied in the US and in some European countries (Autor et al. 2006, 2008; Goos et al. 2009; Spitz-Oener 2006; Green 2012). One central contribution of the task approach was that a refined hypothesis regarding the link between computerization (and offshoring, see Autor and Dorn (2009)) and skill demand change was formulated. Specifically, computerization could replace human labor in jobs where

\footnotetext{
${ }^{3}$ In general, the use of objective measures, such as occupational classifications (as realized matches by mean educational level) and expert ratings of occupational skill requirements, suffers from conflating supply and demand, or not capturing within-occupational heterogeneity, being less actual and possibly also less valid, e.g., because experts' assessments are based on single raters or the unevaluated functional equivalence of occupational classification measures in cross-national applications. McGuinness (2006) and Hartog (2000) provide good overviews of advantages and drawbacks of different measures.
} 
workers perform routine tasks, i.e., job tasks that follow precise, well-understood (codifiable) procedures. Typically, this process would erode the demand for mid-level skilled routine cognitive and manual activities, such as bookkeeping, clerical work, and repetitive production tasks (ibid., routinization hypothesis). In contrast, technology would complement analytical and interactive non-routine job tasks typically performed by high-skilled workers, thereby leading to an increase in their relative demand. Finally, as low-skilled, non-routine manual tasks, such as truck driving and cleaning, are, as yet, not directly affected by computerization (but see Frey and Osborne 2013), their relative demand is assumed to be increasing as well. Studies on the US (Autor et al. 2006), Great Britain (Goos and Manning 2007) and some European countries (Goos et al. 2009) suggest that since the 1990s, rather than upgrading, the relative demand trends for skills are better described as polarization (Spitz-Oener 2006), i.e., relative declines in mid-level skill jobs and relative increases in high- and low-skill jobs. Antonczyk et al. (2010) found evidence of employment polarization in Germany from 1989 to 2004 . By analyzing wage trends, some have found that compared with other countries, in Germany, the increase at the bottom of the skill structure seems to be lower, thus indicating that the overall picture is one of polarized upgrading (Dustmann et al. 2009; Oesch and Rodriguez 2011).

The characteristics of the supply and (as controversially discussed) demand side and the problems with precisely measuring the two sides (cp. footnote 3 ) should be considered when reviewing studies on the incidence rates and wage penalties of mismatching. As an alternative to combining objective measures of skill demand, such as expert ratings and mean education level of occupations, with supply side information, some authors have directly asked respondents what level of education is required for their job and then compared this with their achieved level of education (educational mismatching), or researchers have directly asked whether respondents feel as if there is a mismatch (Green and McIntosh 2007). Compared to the US and UK, there are comparatively few studies on mismatching in Germany. Available studies reveal the following. While there are international averages of approximately $22 \%$ for subjective and $29 \%$ for objective measures (McGuinness 2006) ${ }^{4}$, the few studies for Germany report relatively low average rates for

\footnotetext{
${ }^{4}$ McGuinness (2006) reviews 33 studies between 1969 and 2000 from mostly Western countries, most of which present US and UK (and Britain) data, but they also include data for Holland, Germany, Greece, Spain, Canada, Portugal, (Northern) Ireland, and Hong Kong with a total of 62 estimates. Across studies in their meta-analysis, Groot and Maassen van den Brink (2000) find an average of $23.3 \%$ of workers to be overeducated (based on 50 estimates) and $14.4 \%$ to be under-qualified for their jobs (36 estimates). For a review of existing studies, also see Hartog (2000) and Quintini (2011).
}

both men and women regarding overqualification, with values of $17.5 \%$ based on a measure of formal matching of educational attainment with required level of education using data from 1984 (Daly et al. 2000), 15.8\% using similar data from 1998 (Büchel and van Ham 2003), and 11.5\% using a standard deviation-based measure of educational levels in occupations with data from 1984 to 1998 (Bauer 2002). Daly et al. (2000) compare US and German panel data and find more similarities between countries at one point in time than within one country across time. They conclude that neither structural change nor institutional differences affect the returns to mismatching. A recent cross-national comparative study on graduate overeducation conducted by Verhaest and Van der Velden (2013) shows that overeducation rates of German graduates 6 months after graduation are among the lowest in the 14 countries studied, but that they face an above average persistence of overeducation. With respect to trends, studies with comparable long-term data from Sweden (Korpi and Tåhlin 2009) and the UK (Green 2006) report an increase in overeducation. In an analysis of the BIBB/IAB and BIBB/BAuA Employment Surveys 1979-2006, we find similar growth trends of overqualification in Germany as well (Rohrbach-Schmidt and Tiemann 2011). The Konsortium Bildungsberichterstattung (2006, pp. 185 et seqq.) has shown that formal overqualification has increased for graduates from academic tertiary level institutions from 1984 and 1995 to 2004 (19.8\%) in Germany and, currently, is slightly above the level of overqualification of graduates from upper secondary vocational education and training institutions (2004: 17.2\%).

Distinct from the determinants in countries' overall levels or incidence rates of mismatching, researchers have studied the earnings consequences of mismatching at the worker level, i.e., wage penalties resulting from over- or under-qualification. Based on the decomposition of attained education into required (RE), over- and under-qualifications (OE, UE) the ORU model was first presented in the work of Duncan and Hoffman (1981). Their study indicates that wage regressions reveal a stable pattern in the decomposed coefficients of education across time and countries (Hartog 2000; Rubb 2003a). That is, $\mathrm{OE}>0, \mathrm{UE}<0$, and $|\mathrm{UE}|<\mathrm{RE}>\mathrm{OE}$, which suggest that 'overeducated workers earn more than correctly matched workers in the same type of jobs..., but less than correctly matched workers with the same amount of education' (Korpi and Tåhlin 2009, p. 184) and that there exists a converse pattern for undereducated workers ${ }^{5}$, respectively. This pattern challenges the human capital theory, and thus, there is an ongoing debate on whether, in general, mismatching is a real or an apparent phenomenon and

\footnotetext{
${ }^{5}$ Reviewing available cross-national evidence, Hartog (2000, p. 135) reports that differences in returns to UE would not always be statistically significant.
} 
on whether real mismatching can be explained satisfactorily (see the section below). In a review of studies from different countries and time points on the effects of mismatching on wages, McGuinness (2006) finds large variance in the estimates for required education $(4.8-14 \%)$, overeducation $\left(2.0^{6}-7.1 \%\right)$ and undereducation $(-10.75-1.7)$ across studies. While Bauer (2002) and Daly et al. (2000) present measures for Germany as well, their implications for current wage penalties in Germany give rise to skepticism. For instance, Bauer's measurement seems to conflate supply and demand side information, and Daly et al. estimates are based on data from Germany in 1984. To our knowledge there is no accurate current estimate of the wage penalties from mismatching for Germany (cf. Quintini 2011).

\subsection{Understanding the matching process: productivity, signaling, and self-selection}

The existence of relevant proportions of each nation's labor force being mismatched challenges classic human capital theory (HCT). To be consistent, either mismatching does not exist substantially and the above results are due to unobserved heterogeneity of workers caused by measurement errors or missing controls, such as abilities or skills in wage equations (e.g., see Green and McIntosh 2007), or the observed skill gaps are real but persist for only a short time (Sichermann and Galor 1990). In other words, either overeducated (undereducated) workers are less (more) able than others with similar qualifications, and thus, they are in appropriate jobs with respect to their skills, or mismatching is part of a human capital investment strategy (Chevalier 2003). However, mismatching seems to be a prolonged disequilibrium as there are repeated findings of this phenomenon. If mismatching were only temporary, it could be integrated into HCT with the two above mentioned arguments.

Several authors have attempted to prove the consistency of HCT by using different measures for mismatching and by controlling for as many worker characteristics as possible. In fact, some results based on fixed effects models or on models with controls for ability or job satisfaction indicate that unobserved worker heterogeneity has a relevant role in explaining differences between match categories (Allen and van der Velden 2001; Bauer 2002; Chevalier 2003; Frenette 2004; Green 2006; Green and McIntosh 2007). More recently, analyses from Korpi and Tåhlin (2009) of panel data from Sweden do not provide support for what they call the human capital compensation hypothesis. Moreover, the inclusion of ability and health measures does not affect HC variables, and the fixed effect models and the use of instru-

\footnotetext{
${ }^{6}$ The authors report even negative values for overeducation and positive values for undereducation. However, we do not consider these implausible values in this study.
}

mental variables do not lead to substantial deviations from the above-described pattern. Equally, authors attempting to determine whether mismatching is largely a short-term phenomenon arising from imperfect information or reflecting a strategy of labor market beginners for future wage growth (occupational mobility hypothesis) have met with rather disappointing results (Dolton and Vignoles 2000; Frenette 2004; Korpi and Tåhlin 2009; Rubb 2003b). In a review of the available evidence, Hartog (2000, p. 139) reports that the incidence of mismatching typically decreases with increasing age and experience, whereas results for tenure are mixed. The latter is partly because it is not easy to separate effects from possible matching strategies from other characteristics of labor market beginners (Büchel and Mertens 2004). McGuinness criticizes that none of the studies controls for cohort effects (McGuinness 2006, p. 411).

The mixed results regarding human capital compensation and the occupational mobility hypothesis support the assumption that, at least to some extent, mismatching is a real phenomenon in labor markets. HCT links wages, schooling, and on-the-job training within an equilibrium model. Apparently, HCT, however, does not acknowledge the demand side or job characteristics (Hartog 2000; Lazear 1995). Moreover, it fails to link the practicing of specific bundles of job activities to the skills these workers must have to meet demands (Autor and Handel 2013). In contrast, according to job competition and assignment models, the occurrence of mismatching is assumed to be a real phenomenon (Sattinger 1993; Thurow 1975).

First, these theories consider job heterogeneity to be opposed to or in addition to worker heterogeneity, and as such, it is relevant when considering mismatching. Herein, skill requirements, and thus wages, are also determined by the characteristics of the job, not solely by the qualifications of the worker. It is assumed that not only will some workers be more or less able than other workers, but that jobs will be held by over- or undereducated workers who have higher (or lower) skill requirements than those observable simply by levels of education (Korpi and Tåhlin 2009). If this is the case, the inclusion of better measures for the skill requirements of jobs, such as task content and changes in requirements over time, in matching models would provide validation of the concept and measure of overqualification. In contrast to heterogeneous ability assumptions, one might assume that overqualification is less common in jobs characterized by complex abstract tasks and sharp increases in skill requirements over time.

Second, in these other theories, mismatch is regarded as a real phenomenon where over- and underqualified individuals have jobs that are inappropriate for their skill levels and abilities. Job competition models suggest that for a given job opportunity, the allocation of a specific individual to that job is based on his relative position in the job queue, which 
is determined by the value of his trainability as signaled to the employer by the applicant's schooling and experience (Kalleberg 1996; Sørensen and Kalleberg 1981; Spence 1973). As such, skills that are relevant for the job, to a large extent, are acquired during on-the-job training. From this perspective, educational overinvestment may result from an over- or undersupply of qualifications in the market. Within that framework, previously adequately matched workers may suddenly find themselves undereducated and thus knocked down a few rungs in the labor market due to changing hiring standards. The placement of overeducated workers in lower level occupations would thus lead to an increase in the mean educational level within these occupations (McGuinness 2006, p. 388). With respect to the UK, Goos and Manning (2007) argue that an increase in overeducation might result from the concurrence of the steady increase in educational attainment, the decrease in mid-level skill jobs, and the rising credentialism at the bottom of the occupational hierarchy (Goos and Manning 2007, p. 128-9). From this and similar polarization trends in Germany, one would assume a positive correlation of lower level occupations and overqualification in our data. Against the background of the ALM framework, one possibility to test this assumption is to use job tasks instead of occupational level as the measures for skill requirements of jobs. Thus, because of a polarization trend in skill demand in Germany, workers in jobs characterized by cognitive or manual routine tasks and non-routine manual tasks should have higher odds of being mismatched with respect to their formal qualifications and skills than workers in jobs with higher level tasks.

Yet, especially for German vocational training certificates it is the case that graduates are equipped with surplus skills and competences they do not use in their specific held occupations (Lutz and Grünert 2003). 'A vocational training occupation is defined as a bundle of qualifications that are learned, assessed and certified in an institutionalized training which enables the graduate to work in a number of similar occupations.' (Tiemann 2015). Those trainings are regularly adapted to current developments and new requirements. Even if one of the occupational activities open for employees with a training certificate goes extinct, there are still other activities on the same qualification level the holder could change into. So, either workers would select to different jobs on the same level or the training would be adapted. So one might instead assume that many routine manual jobs might provide better protection against overqualification because jobs intensive in these tasks are often occupations that are trained in the German VET system with clearly defined skill requirements.

Further insight of assignment models indicates that they assume workers' choices over job opportunities through utility maximization strategies (Autor and Handel 2013; Müller et al. 2002; Sattinger 1993). According to this thinking, individuals self-select into those jobs for which they have an offer that afford them the highest utility. Thus, as Green and McIntosh (2007) argue, some workers might choose the most appropriate job within reach based on their skills and given their time resources. In fact, Büchel and Battu (2003) have shown that married West German women living in rural areas exhibit higher odds of overqualification. Thus, as an alternative explanation to the imbalance of the supply and demand of workers, mismatching might result from labor market rigidities. Workers with specific family responsibilities, such as caring for children or relatives, might, for example, choose part-time jobs that are within their reach, even if these jobs are not perfectly matched to their skills.

In sum, previous research gives reason to assume that beyond human capital compensation and career mobility rationalities, job characteristics may help to explain mismatching and its real or apparent wage penalties. To test the validity of the worker and job heterogeneity assumptions as discussed herein, we empirically examine the incidence rates and wage penalties of mismatching in Germany. To this end, we differentiate between educational and skillrelated mismatching and consider several precise measures of worker and job characteristics.

\section{Data, variables, and methods}

\subsection{Data and variables}

In Germany, there is a survey designed specifically to assess mismatching that uses rich information collected via the job requirement approach (JRA). The BIBB/BAuA Employment Survey $2006^{7}$ (Hall and Tiemann 2009) is a representative cross-sectional survey on qualifications and working conditions in Germany. It includes information on respondents' qualifications and career history as well as detailed job-related information, including organizational information, job tasks, job skill requirements, working conditions, health etc. With a sample size of 20,000, it also studies special social groups, such as older individuals, females, non-formally qualified workers, and workers with different national backgrounds, as well as developments within detailed occupations, industries and vocational fields. The study population is people who belong to the labor force, i.e., receive pay for work, who are aged 15 and over, and who have a regular work schedule of at least $10 \mathrm{~h}$ per week. The sampling design is a two-stage probability sampling with households as the primary sampling units (Gabler-Häder sampling frame) and individuals

\footnotetext{
${ }^{7}$ There are four earlier cross-sectional surveys from 1979, 1985 , 1991/1992 and 1998/1999. A sixth Employment Survey has been fielded in 2011/2012 (Hall et al. 2015).
} 
as secondary sampling units (Kish sampling frame). The non-response rate was $56.0 \%$.

Whereas most studies rely on overeducation alone, the data used here allow for observing both educational and skills mismatch. To measure educational (mis)matching, we use the respondents' educational attainment above compulsory general education ${ }^{8}$ and the respondents' assessment of the typical qualifications required to perform their current job9. The ordinal categories, from lowest to highest, are as follows: no vocational education and no training qualification; completed dual/school-based vocational education and training (VET) qualification; master craftsman or technician qualification or trade and technical school qualifications; university qualification. These categories are surveyed using the same wording in both questions. In this way, the matching categories can be computed easily ${ }^{10}$. In addition to the overall indicator variable, in some of our wage models, we include specific ORU variables for the categorically different German vocational degrees to indicate whether a respondent is overeducated with a completed vocational education and training qualification, with a university degree, etc. To measure skill mismatching, we rely on workers' subjective assessment of mismatching. Respondents were asked whether they generally feel they are comfortable with, overchallenged, or underchallenged by the requirements of their current job given their occupational knowledge and skills. In contrast to formal matching, this measure more closely reflects the degree of matching between the skills and the knowledge of the job holder and the job's skill requirements.

Against the background of the above discussed theories, as regards worker heterogeneity, we include the sociodemographic variables, i.e., age cohort, sex, marital status, children living in the household, migration background (not having learnt German as a first language), and place of residence (East vs. West Germany). Human capital variables include highest educational degree achieved (reclassified in

\footnotetext{
${ }^{8}$ If respondents do not have vocational qualification or tertiary-level qualification, they are classified as having 'no vocational education and training qualification'.

${ }^{9}$ Respondents were asked, "What kind of qualification is usually required to perform your job as a $<$ current main job $>$ ?"

${ }^{10}$ The typically required vocational education was adjusted with information on how long it takes to get acquainted with the job's tasks and whether special courses had to be visited, where a typical threshold is 1 year of further education. This is due to possible misunderstandings of the difference between courses leading to a technician or master's degree and courses giving extra skills but no formal qualification. There are also some certificates for technicians that might be awarded through vocational education. On the other hand, there are a number of surveying positions held by formally underqualified employees. It is also the case that some academically trained employees do not realize that vocational education was required for their jobs, albeit their academic qualification was the requirement. In these cases, the required vocational education was adjusted accordingly.
}

ISCED-97 $7^{11}$ with level B indicating vocational qualifications and virtual years of education ${ }^{12}$ ) and labor market experience in years (interview year minus years of employment gaps minus year of first employment $\left.{ }^{13}\right)$. Moreover, we use the information about the year since the worker began performing the current job-activity (task experience). We also control for a dummy measuring whether there was at least one employment gap in the respondent's career (the length being included in labor market experience). To capture differences in productive capacity, we also consider the state of health, ranging from poor (1) to excellent/perfect (5).

In addition, we examine the role of job characteristics in mismatching. In this approach, we condition the self-assessment of requirements, which may be biased, using objective information on the skill requirements of jobs. We use task measures for jobs that demand higher skills from workers, such as analytic, interactive, non-routine job tasks, and medium to low skills, such as routine manual, routine cognitive, and non-routine manual job tasks, each ranging from 0 to $100^{14}$.We also aggregate these measures at the occupational level to control for changing skill demand. Moreover, we include a dummy for workers' responses when asked whether the skill requirements within their jobs have increased (with stability and decrease of requirements as the referent). We also include dummies for employment status (blue-collar (referent), white-collar, public servant, selfemployed, free-lancer ${ }^{15}$, helping family member), supervi-

\footnotetext{
${ }^{11}$ ISCED level 3B (completed vocational education and training qualification) also comprises graduates from $3 \mathrm{~B}$ with additional post-secondary non-tertiary education (ISCED 4). ISCED 5B includes master craftsmen, technicians, and workers with trade and technical school qualifications; ISCED 5A comprises university graduates.

${ }^{12}$ Virtual years of education were computed by adding up the time it usually takes to achieve a certain degree. For example, to achieve a bachelor's degree one would typically have attended general school for 13 years, of which nine are in secondary education, plus 3 years at a university. In sum, you would get a score of 16 years for virtual education.

${ }^{13}$ Some respondents have accomplished, or at least started, more than one vocational education or training program. For some of these cases, the time of the first training episode had to be recomputed.

${ }^{14}$ Each single task measure is the worker's assessed number of activities performed in one category divided by the total number of activities in the category multiplied by 100 . In contrast to former waves and thus to the procedures in Spitz-Oener (2006), it is possible to weight the number of activities by whether they are performed frequently (with a weight of 1 ), sometimes (with a weight of 0.5 ) or never (with a weight of 0 ). The categorization of single tasks to these tasks can be found in Table 8 of the appendix.

${ }^{15} \mathrm{We}$ are aware of the possible problems due to reporting errors of selfemployed or free-lancing workers on their income. We do measure gross earnings and find that self-employed and free-lancers show the highest mean income with the highest standard deviation. The imputation of missing cases in gross earnings is probably responsible for the high deviation. Self-employed and free-lancers are still included in the sample, though they will likely have distinct task-profiles.
} 
Table 1 Descriptive statistics. (Source: BIBB/BAuA Employment Survey 2006)

\begin{tabular}{|c|c|c|c|c|}
\hline & Mean & Std.dev & Min & Max \\
\hline Overqualified & 0.18 & 0.38 & 0 & 1 \\
\hline Overskilled & 0.13 & 0.33 & 0 & 1 \\
\hline ISCED 3B (Vocational education and training qual.) & 0.63 & 0.48 & 0 & 1 \\
\hline ISCED 5B (Master craftsmen, technicians, trade/technical school qual.) & 0.07 & 0.26 & 0 & 1 \\
\hline ISCED 5A (University degree) & 0.30 & 0.46 & 0 & 1 \\
\hline \multicolumn{5}{|l|}{ Required Education (RE) } \\
\hline $\mathrm{RE}$ - no vocational degree & 0.09 & 0.28 & 0 & 1 \\
\hline $\mathrm{RE}-3 \mathrm{~B}$ & 0.58 & 0.49 & 0 & 1 \\
\hline $\mathrm{RE}-5 \mathrm{~B}$ & 0.07 & 0.25 & 0 & 1 \\
\hline $\mathrm{RE}-5 \mathrm{~A}$ & 0.27 & 0.44 & 0 & 1 \\
\hline \multicolumn{5}{|l|}{ Overeducated (OE) } \\
\hline $\mathrm{OE}-3 \mathrm{~B}$ & 0.08 & 0.27 & 0 & 1 \\
\hline $\mathrm{OE}-5 \mathrm{~B}$ & 0.04 & 0.19 & 0 & 1 \\
\hline $\mathrm{OE}-5 \mathrm{~A}$ & 0.06 & 0.24 & 0 & 1 \\
\hline \multicolumn{5}{|l|}{ Undereducated (UE) } \\
\hline $\mathrm{UE}-3 \mathrm{~B}$ & 0.05 & 0.22 & 0 & 1 \\
\hline$U E-5 B$ & 0.01 & 0.08 & 0 & 1 \\
\hline Log hourly wages & 2.76 & 0.49 & -0.24 & 5.66 \\
\hline Females & 0.49 & 0.50 & 0 & 1 \\
\hline \multicolumn{5}{|l|}{ Age cohort } \\
\hline $25-34$ & 0.24 & 0.43 & 0 & 1 \\
\hline $35-44$ & 0.38 & 0.49 & 0 & 1 \\
\hline $45-54$ & 0.27 & 0.45 & 0 & 1 \\
\hline $55-64$ & 0.11 & 0.31 & 0 & 1 \\
\hline Kid(s) living in the household & 0.47 & 0.50 & 0 & 1 \\
\hline German not learnt as a first language & 0.05 & 0.21 & 0 & 1 \\
\hline Married & 0.57 & 0.50 & 0 & 1 \\
\hline Residence in East Germany & 0.19 & 0.40 & 0 & 1 \\
\hline Virtual education (yrs.) & 0 & 2.46 & -4.27 & 3.23 \\
\hline Labor force experience (yrs.) & 0 & 10.0 & -18.8 & 30.7 \\
\hline Employment gap & 0.54 & 0.50 & 0 & 1 \\
\hline Task experience (yrs.) & 0 & 7.78 & -8.56 & 35.4 \\
\hline \multicolumn{5}{|l|}{ Health } \\
\hline $1=$ Very bad & 0.01 & 0.12 & 0 & 1 \\
\hline 2 & 0.08 & 0.27 & 0 & 1 \\
\hline 3 & 0.53 & 0.50 & 0 & 1 \\
\hline 4 & 0.26 & 0.44 & 0 & 1 \\
\hline $5=$ Excellent & 0.11 & 0.31 & 0 & 1 \\
\hline Non-routine analytic job tasks & 0 & 25.9 & -56.0 & 44.0 \\
\hline Non-routine interactive tasks & 0 & 30.2 & -58.5 & 41.5 \\
\hline Routine cognitive job tasks & 0 & 30.9 & -35.0 & 65.1 \\
\hline Routine manual job tasks & 0 & 28.6 & -34.0 & 66.0 \\
\hline Non-routine manual job tasks & 0 & 26.4 & -21.1 & 78.9 \\
\hline Increase in job skill requirements & 0.56 & 0.50 & 0 & 1 \\
\hline Shift work & 0.23 & 0.42 & 0 & 1 \\
\hline Part-time job & 0.23 & 0.42 & 0 & 1 \\
\hline Non-routine analytic job tasks (occ. mean) & 0 & 15.6 & -37.3 & 23.8 \\
\hline Non-routine interactive tasks (occ. mean) & 0 & 17.0 & -35.9 & 38.7 \\
\hline Routine cognitive job tasks (occ. mean) & 0 & 9.8 & -13.0 & 35.1 \\
\hline Routine manual job tasks (occ. mean) & 0 & 17.9 & -18.2 & 41.1 \\
\hline Non-routine manual job tasks (occ. mean) & 0 & 14.0 & -11.4 & 39.5 \\
\hline Increase in job skill req. (occ. mean) & 0 & 9.0 & -30.5 & 15.8 \\
\hline$N_{i}$ & 14,266 & & & \\
\hline
\end{tabular}

Sample excludes workers aged 15-24 and 65+ and workers without a vocational degree (for detailed sample definition see Sect. 3.1). All continuous level-1 and level-2 variables are centered around their (grand) mean (see Sect. 3.2) 
sor, part-time, or shift work and firm size, with categories ranging from 1 to 11 (1500 employees). With respect to outcomes from (mis)matching, we examine wage penalties (log hourly gross income as a dependent variable $\left.{ }^{16}\right)$.

We restrict the analysis to workers aged 25-64 in order to focus on prime-aged employees whose labor force participation is high. With this, 1209 cases are dropped from the total sample. We also drop observations with their job's economic sector being a private household or a sector not else classified $(n=382)$. To further strengthen the analysis we restrict the sample to 2-digit occupations with a least 50 cases (three occupational sub-major groups and 48 cases are dropped). First, we characterize the incidence of educational and skill mismatch in this core workforce population $(n=18,361)$. Second, we estimate several multivariate models of mismatching and wages. In these models, only those cases are considered that can in principle be at risk of overqualification, i.e. workers with at least an ISCED 3B (2nd level of vocational education) certificate. Thus, another 1245 cases with ISCED 0, 2A, 2B and 3A are excluded. Finally, only cases with information on all variables considered in the matching and wage models enter the estimation $(n=14,266)$.

Because of women's unstable labor market participation over their lifecycle all models are estimated for men $(n=7,268)$ and women $(n=6,998)$ separately (tables on request). We report decisive differences to the pooled analyses in the results section.

Table 1 includes summary statistics for main variables used in the multivariate analyses.

\subsection{Methods}

To test for the assumption that above worker characteristics job heterogeneity has a role in explaining a mismatch, we run a set of multivariate models of mismatching and wages where we explicitly control for variance at the occupation level. First, with (mis)matching as the dependent variable, we regress the probability of being (mis)matched on worker and job variables simultaneously within a random intercept logistic regression model with workers nested in occupations. In the same vein, in the second part, we calculate wage penalties from mismatching in a random intercept linear model for workers within occupations. The model is written as:

$$
Y_{i j}=\gamma_{00}+\gamma_{10} X_{i j}+\gamma_{01} Z_{j}+u_{0 j}+u_{1 j} X_{i j}+e_{i j}
$$

\footnotetext{
${ }^{16}$ We use imputed values for cases with missing information on the original self-reported gross monthly earnings variable (Alda and Rohrbach-Schmidt 2011).
}

Table 2 Educational and skills (mis)match. (Source: BIBB/BAuA Employment Survey 2006)

\begin{tabular}{lll}
\hline Matching category & Frequency & Percent \\
\hline Formal match & & \\
Undereducated & 1850 & 10.1 \\
Matched & 13,094 & 71.4 \\
Overeducated & 3404 & 18.6 \\
$\mathrm{~N}$ & 18,348 & 100.0 \\
Skills match & & \\
Underskilled & 840 & 4.6 \\
Matched & 15,099 & 82.4 \\
Overskilled & 2395 & 13.1 \\
$\mathrm{~N}$ & 18,333 & 100.0 \\
\hline
\end{tabular}

Sample excludes workers aged 15-42 and 65+ (for detailed sample definition see Sect. 3.1. Figures are weighted by survey weight

where $Y_{i j}=\operatorname{Logit}\left(\pi_{\mathrm{ij}}\right), \pi_{\mathrm{ij}}=\mathrm{P}\left(\mathrm{y}_{\mathrm{ij}}=1 \mid \mathrm{x}_{\mathrm{ij}}, \mathrm{z}\right)$, and $\operatorname{logit}\left(\pi_{\mathrm{ij}}\right)=\ln$ $\pi_{\mathrm{ij}} / 1-\pi_{\mathrm{ij}}$ in the logistic case; where workers $\mathrm{i}\left(\mathrm{n}_{\mathrm{i}}=14,266\right.$, i.e. 7,268 for men and 6,998 for women) are nested in occupations $\mathrm{j}\left(\mathrm{n}_{\mathrm{j}}=25\right.$ with $n_{i} \geq 54$ and $n_{i} \leq 2,030$, and mean $\left.n_{i}=570.6\right)$; where regression coefficients are denoted by $\gamma$; where $(\mathrm{X})$ denotes explanatory variables at the workerlevel; $(Z)$ denotes the occupation-level; $\mathrm{u}_{0 \mathrm{j}}, \mathrm{u}_{\mathrm{ij}}, \mathrm{e}_{\mathrm{ij}}$ are the residual error terms at the occupation and the worker levels, respectively, with a mean of zero; and where $\mathrm{u}_{0 \mathrm{j}}, \mathrm{u}_{1 \mathrm{j}}$ are independent of $\mathrm{e}_{\mathrm{ij}}$.

In both regressions, we use variable information as previously described herein. All continuous level-1 and level-2 variables are centered around their (grand) mean. To separate within- and between-effects of occupational characteristics, job variance at the worker level (job task groups) is also aggregated at the occupation level (ISCO-88 sub-major groups (two-digit)). Explicitly, modeling the multilevel structure of the data as a system of regression equations in which the lowest level variable is simultaneously regressed on covariates from all existing levels, the multilevel models $^{17}$ satisfy statistical and conceptual adequacy (Hox 2002; Rabe-Hesketh and Skrondal 2008; Raudenbush and Bryk 2002). We estimate the probabilities of mismatching and the mismatching penalties using the xtmelogit (adaptive Gaussian quadrature and seven integration points) and the xtmixed command in Stata, respectively. For mismatching models we report average marginal effects (discrete changes in case of factor variables) in addition to factor changes (odds ratios).

\footnotetext{
${ }^{17}$ In the economic literature, multilevel models are also known as random coefficient models or mixed models.
} 
Table 3 Two-way cross-tabulation of educational and skill (mis) match. (Source: BIBB/BAuA Employment Survey 2006. Sample excludes workers aged $15-24$ and $65+$ (for detailed sample definition see Sect. 3.1). Figures are weighted by survey weight)

\begin{tabular}{|c|c|c|c|c|}
\hline \multirow{2}{*}{$\begin{array}{l}\text { Educational } \\
\text { match }\end{array}$} & \multicolumn{4}{|c|}{ Skill match } \\
\hline & Under-skilled & Match & Over-skilled & Total \\
\hline $\begin{array}{l}\text { Under- } \\
\text { educated }\end{array}$ & $\begin{array}{l}\text { Real Underqualification } \\
0.6(115)\end{array}$ & $\begin{array}{l}\text { Undereducation } \\
8.4(1,536)\end{array}$ & $1.1(197)$ & $10.1(1,847)$ \\
\hline Match & $\begin{array}{l}\text { Underskilling } \\
3.3(604)\end{array}$ & $\begin{array}{l}\text { Underqualification } \\
\text { 10.1 (1,850) } \\
\text { Real Match } \\
60.4(11,063) \\
\text { Overqualification } \\
\quad 24.7(3,761)\end{array}$ & $\begin{array}{l}\text { Overskilling } \\
7.7(1,412)\end{array}$ & $71.4(13,079)$ \\
\hline $\begin{array}{l}\text { Over- } \\
\text { educated }\end{array}$ & $0.6(117)$ & $\begin{array}{l}\text { Overeducation } \\
13.6(2,495)\end{array}$ & $\begin{array}{l}\text { Real over- } \\
\text { qualification } \\
4.3 \text { (783) }\end{array}$ & $18.5(3,395)$ \\
\hline Total & $4.6(836)$ & $82.4(15,093)$ & $13.1(2,392)$ & $100.0(18,321)$ \\
\hline
\end{tabular}

Table 4 Variance composition of match categories in intercept-only models. (Source: BIBB/BAuA Employment Survey 2006)

\begin{tabular}{|c|c|c|c|c|c|c|}
\hline & $\begin{array}{l}\text { Overedu } \\
\text { cation }\end{array}$ & $\begin{array}{l}\text {-Education- } \\
\text { al Match }\end{array}$ & $\begin{array}{l}\text { Underedu- } \\
\text { cation }\end{array}$ & $\begin{array}{l}\text { Over- } \\
\text { skilling }\end{array}$ & $\begin{array}{l}\text { Skill } \\
\text { Match }\end{array}$ & $\begin{array}{l}\text { Under- } \\
\text { skilling }\end{array}$ \\
\hline$\sigma_{u 0 j}^{2}$ & $\begin{array}{l}0.971 \\
(0.292)\end{array}$ & $\begin{array}{l}0.575 \\
(0.172)\end{array}$ & $\begin{array}{l}1.02 \\
(0.366)\end{array}$ & $\begin{array}{l}0.295 \\
(0.093)\end{array}$ & $\begin{array}{l}0.196 \\
(0.063)\end{array}$ & $\begin{array}{l}0.016 \\
(0.017)\end{array}$ \\
\hline$I C C$ & 0.228 & 0.148 & 0.236 & 0.082 & 0.056 & 0.005 \\
\hline $\mathrm{N}_{\mathrm{i}}$ & 14,266 & 14,266 & 14,266 & 14,266 & 14,266 & 14,266 \\
\hline $\mathrm{N}_{\mathrm{j}}$ & 25 & 25 & 25 & 25 & 25 & 25 \\
\hline
\end{tabular}

ICC $=$ Fraction of total variance in each mismatching category that is due to occupation-level variance ( $\sigma_{u 0 j}^{2}$ with s.e. in parentheses)

Sample excludes workers aged 15-24 and $65+$ and workers without a vocational degree (for detailed sample definition see Sect. 3.1)

\section{Results}

4.1 Incidence and determinants of formal and skill-based mismatching in Germany

Table 2 plots separately the incidence of formal and skillbased mismatching. We see that matching in terms of skills at $82.4 \%$ is more frequent than formal matching at $71.4 \%$. For both measures, there are larger shares of workers with education and skills above rather than below the required level. Pearson's chi-squared indicates that the mismatching measures are significantly related, but with a value of Cramér's V of .10 the relationship between the variables is rather low. This parallels the findings for Dutch and UK data (Green and McIntosh 2007). Cross-tabulating both matching measures (cf. Table 3 ) confirms that, to a sizable extent, the different types of (mis)matching are independent of one another (for a similar approach see Green and Zhu 2010): Real mismatches, i.e., overqualification or underqualification in both educational and skills-based terms, are extremely rare in Germany at $4.3 \%$ and $0.6 \%$, respectively. A larger share of workers is inappropriately employed with respect to their formal qualifications at $13.6 \%$ and $8.4 \%$. A skill-based mismatch without an educational mismatch occurs less frequently (7.7\% and 3.3\%). Thus, as Green and McIntosh (2007) demonstrated for the UK, workers in
Germany can also be mismatched in terms of their education, even though their skills or abilities are, in fact, appropriate for the jobs they do. Additionally, there are workers who are perfectly matched with regards to the educational requirements, yet nevertheless, they feel under- or overchallenged by their jobs' skill requirements. Based on this decomposition, $60.4 \%$ of workers are matched, $24.7 \%$ are overqualified and $10.1 \%$ are underqualified. Ultimately, these descriptive results indicate that mismatching rates in Germany are comparatively low, particularly compared with those of Anglo-Saxon countries (cf. McGuinness 2006; Groot and Maassen van den Brink 2000).

To see whether the self-reported mismatching measures capture the two intended dimensions of mismatching, we inspect the decomposed matching categories by worker and job characteristics ${ }^{18}$. Overall, the measures are validated. Most notably, the breakdowns of mismatching for different ISCED-levels (highest level attained) confirm certain decisive matching patterns in Germany. First, workers with a completed vocational education and training qualification (ISCED 3B, 64\% matched), and university graduates (ISCED 5A, 67\% matched) perform equally well in obtaining a job for which they are 'really' matched. A lower level degree from the VET system (ISCED 3B), which equips individuals with specific human capital, involves lower rates of mismatching than higher-level degrees of general education (3A, 23\% 'really' matched). This clearly emphasizes the position of the VET system in Germany. Lower (higher) educated workers have above average shares of undereducation (overeducation), but medium and low qualified workers claim to underutilize their skills more often than workers with a tertiary level degree. Notable differences within the matching categories also emerge with regard to job tasks. In jobs characterized by complex abstract tasks and a sharp rise in skill requirements over time, educational mismatching is

\footnotetext{
${ }^{18}$ Bivariate statistics for mismatching by socio-demographic variables and several human capital variables as well as by job characteristics can be requested from the authors.
} 
Table 5 Random intercept model of overeducation $(n=14,266)$. (Source:BIBB/BAuA Employment Survey 2006)

\begin{tabular}{|c|c|c|c|c|c|c|c|c|}
\hline & $\begin{array}{l}1) \\
\text { O.R. }\end{array}$ & $\begin{array}{r}\mathrm{AME} / \\
\mathrm{DC}\end{array}$ & $\begin{array}{r}(2) \\
\text { O.R. }\end{array}$ & $\mathrm{AME} / \mathrm{DC}$ & $\begin{array}{l}3) \\
\text { O.R. }\end{array}$ & $\mathrm{AME} / \mathrm{DC}$ & $\begin{array}{l}4) \\
\text { O.R. }\end{array}$ & $\mathrm{AME} / \mathrm{DC}$ \\
\hline \multicolumn{9}{|l|}{ Age cohort (Ref.:25-34) } \\
\hline $35-44$ & $\begin{array}{l}1.106 \\
(1.37)\end{array}$ & 0.012 & & & $\begin{array}{l}1.035 \\
(0.44)\end{array}$ & 0.004 & $\begin{array}{l}1.035 \\
(0.44)\end{array}$ & 0.003 \\
\hline $45-54$ & $\begin{array}{l}1.037 \\
(0.44)\end{array}$ & 0.004 & & & $\begin{array}{l}0.917 \\
(-0.97)\end{array}$ & -0.009 & $\begin{array}{l}0.921 \\
(-0.92)\end{array}$ & -0.008 \\
\hline $55-64$ & $\begin{array}{l}1.119 \\
(0.98)\end{array}$ & 0.013 & & & $\begin{array}{l}0.915 \\
(-0.71)\end{array}$ & -0.009 & $\begin{array}{l}0.917 \\
(-0.70)\end{array}$ & -0.008 \\
\hline \multicolumn{9}{|l|}{ ISCED (Ref.: 5A, univers.deg.) } \\
\hline $\begin{array}{l}3 \mathrm{~B} \text { (vocational education and } \\
\text { training qual.) }\end{array}$ & $\begin{array}{l}0.024^{* * *} \\
(-32.28)\end{array}$ & -0.577 & & & $\begin{array}{l}0.010^{* * *} \\
(-34.50)\end{array}$ & -0.552 & $\begin{array}{l}0.010^{* * *} \\
(-34.53)\end{array}$ & -0.494 \\
\hline $\begin{array}{l}\text { 5B (Master craftsmen, } \\
\text { technicians,trade/technical } \\
\text { school qual.) }\end{array}$ & $\begin{array}{l}1.102 \\
(0.98)\end{array}$ & 0.020 & & & $\begin{array}{l}1.210 \\
(1.79)\end{array}$ & 0.030 & $\begin{array}{l}1.201 \\
(1.72)\end{array}$ & 0.023 \\
\hline Virtual education (yrs.) & $\begin{array}{l}0.855^{* * *} \\
(-8.22)\end{array}$ & -0.019 & & & $\begin{array}{l}0.900^{* * *} \\
(-5.15)\end{array}$ & -0.011 & $\begin{array}{l}0.901^{* * *} \\
(-5.11)\end{array}$ & -0.010 \\
\hline Employment gap & $\begin{array}{l}1.414^{* * *} \\
(6.01)\end{array}$ & 0.041 & & & $\begin{array}{l}1.266^{* * *} \\
(3.82)\end{array}$ & 0.025 & $\begin{array}{l}1.264^{* * *} \\
(3.79)\end{array}$ & 0.022 \\
\hline Task experience (yrs.) & $\begin{array}{l}0.968^{* * *} \\
(-7.43)\end{array}$ & -0.004 & & & $\begin{array}{l}0.977^{* * *} \\
(-5.05)\end{array}$ & -0.002 & $\begin{array}{l}0.977^{* * *} \\
(-5.09)\end{array}$ & -0.002 \\
\hline \multicolumn{9}{|l|}{ Health (Ref.: $1=$ Very bad) } \\
\hline 2 & $\begin{array}{l}0.882 \\
(-0.57)\end{array}$ & -0.016 & & & $\begin{array}{l}0.943 \\
(-0.25)\end{array}$ & -0.007 & $\begin{array}{l}0.938 \\
(-0.27)\end{array}$ & -0.007 \\
\hline 3 & $\begin{array}{l}0.688 \\
(-1.81)\end{array}$ & -0.047 & & & $\begin{array}{l}0.734 \\
(-1.40)\end{array}$ & -0.034 & $\begin{array}{l}0.730 \\
(-1.43)\end{array}$ & -0.031 \\
\hline 4 & $\begin{array}{l}0.586^{*} \\
(-2.53)\end{array}$ & -0.066 & & & $\begin{array}{l}0.643^{*} \\
(-1.96)\end{array}$ & -0.048 & $\begin{array}{l}0.641^{*} \\
(-1.98)\end{array}$ & -0.043 \\
\hline $5=$ Excellent & $\begin{array}{l}0.595^{*} \\
(-2.35)\end{array}$ & -0.064 & & & $\begin{array}{l}0.693 \\
(-1.56)\end{array}$ & -0.040 & $\begin{array}{l}0.691 \\
(-1.57)\end{array}$ & -0.037 \\
\hline Female & $\begin{array}{l}2.567^{* * *} \\
(14.41)\end{array}$ & 0.113 & & & $\begin{array}{l}1.986^{* * *} \\
(9.26)\end{array}$ & 0.073 & $\begin{array}{l}2.005^{* * *} \\
(9.40)\end{array}$ & 0.066 \\
\hline Kid(s) living in the household & $\begin{array}{l}0.979 \\
(-0.35)\end{array}$ & -0.003 & & & $\begin{array}{l}0.967 \\
(-0.49)\end{array}$ & -0.003 & $\begin{array}{l}0.966 \\
(-0.52)\end{array}$ & -0.003 \\
\hline $\begin{array}{l}\text { German not learnt as a first } \\
\text { language }\end{array}$ & $\begin{array}{l}1.249 \\
(1.93)\end{array}$ & 0.027 & & & $\begin{array}{l}1.069 \\
(0.53)\end{array}$ & 0.007 & $\begin{array}{l}1.071 \\
(0.55)\end{array}$ & 0.007 \\
\hline $\begin{array}{l}\text { Married (Ref.: unmarried, } \\
\text { divorced) }\end{array}$ & $\begin{array}{l}1.074 \\
(1.16)\end{array}$ & 0.009 & & & $\begin{array}{l}1.090 \\
(1.30)\end{array}$ & 0.009 & $\begin{array}{l}1.090 \\
(1.30)\end{array}$ & 0.008 \\
\hline $\begin{array}{l}\text { Residence in East Germany } \\
\text { (Ref.: West Germany) }\end{array}$ & $\begin{array}{l}0.826^{* *} \\
(-2.81)\end{array}$ & -0.023 & & & $\begin{array}{l}0.687^{* * *} \\
(-5.12)\end{array}$ & -0.038 & $\begin{array}{l}0.687^{* * *} \\
(-5.13)\end{array}$ & -0.034 \\
\hline Non-routine analytic job tasks & & & $\begin{array}{l}0.990^{* * *} \\
(-7.99)\end{array}$ & -0.0014 & $\begin{array}{l}0.975^{* * *} \\
(-15.17)\end{array}$ & -0.00326 & $\begin{array}{l}0.976^{* * *} \\
(-14.92)\end{array}$ & -0.0023 \\
\hline Non-routine interactive tasks & & & $\begin{array}{l}0.996^{* * *} \\
(-4.30)\end{array}$ & -0.0006 & $\begin{array}{l}0.989^{* * *} \\
(-8.91)\end{array}$ & -0.0012 & $\begin{array}{l}0.989^{* * *} \\
(-8.75)\end{array}$ & -0.0011 \\
\hline Routine cognitive job tasks & & & $\begin{array}{l}1.002^{*} \\
(2.03)\end{array}$ & 0.0002 & $\begin{array}{l}1.005^{* * *} \\
(5.25)\end{array}$ & 0.0006 & $\begin{array}{l}1.005^{* * *} \\
(5.20)\end{array}$ & 0.0005 \\
\hline Routine manual job tasks & & & $\begin{array}{l}0.993^{* * *} \\
(-5.73)\end{array}$ & -0.0009 & $\begin{array}{l}0.996^{* *} \\
(-3.08)\end{array}$ & -0.0005 & $\begin{array}{l}0.996^{* *} \\
(-3.14)\end{array}$ & -0.0004 \\
\hline Non-routine manual job tasks & & & $\begin{array}{r}1.001 \\
(0.90)\end{array}$ & 0.0001 & $\begin{array}{l}1.003^{*} \\
(2.34)\end{array}$ & 0.0004 & $\begin{array}{l}1.003^{*} \\
(2.32)\end{array}$ & 0.0003 \\
\hline Increase in job skill req. & & & $\begin{array}{l}0.789^{* * *} \\
(-4.83)\end{array}$ & -0.033 & $\begin{array}{l}0.727^{* * *} \\
(-5.32)\end{array}$ & -0.034 & $\begin{array}{l}0.726^{* * *} \\
(-5.34)\end{array}$ & -0.030 \\
\hline Shift work & & & $\begin{array}{r}1.036 \\
(0.59)\end{array}$ & 0.005 & $\begin{array}{l}1.523^{* * *} \\
(5.63)\end{array}$ & 0.046 & $\begin{array}{l}1.537^{* * *} \\
(5.77)\end{array}$ & 0.042 \\
\hline Part-time job & & & $\begin{array}{r}1.176^{* *} \\
(2.81)\end{array}$ & 0.023 & $\begin{array}{l}1.280^{* *} \\
(3.12)\end{array}$ & 0.027 & $\begin{array}{l}1.292^{* *} \\
(3.23)\end{array}$ & 0.025 \\
\hline $\begin{array}{l}\text { N.-r. analytic job tasks (occ. } \\
\text { mean) }\end{array}$ & & & & & & & $\begin{array}{l}0.951^{* *} \\
(-2.72)\end{array}$ & -0.0047 \\
\hline $\begin{array}{l}\text { N.-r. interactive job tasks (occ. } \\
\text { mean) }\end{array}$ & & & & & & & $\begin{array}{l}0.949^{* *} \\
(-3.02)\end{array}$ & -0.0050 \\
\hline
\end{tabular}


Table 5 (continued)

\begin{tabular}{|c|c|c|c|c|c|c|c|c|}
\hline & $\begin{array}{l}(1) \\
\text { O.R. }\end{array}$ & $\begin{array}{r}\mathrm{AME} / \\
\mathrm{DC}\end{array}$ & $\begin{array}{l}(2) \\
\text { O.R. }\end{array}$ & $\mathrm{AME} / \mathrm{DC}$ & $\begin{array}{l}\text { (3) } \\
\text { O.R. }\end{array}$ & AME/DC & $\begin{array}{l}(4) \\
\text { O.R. }\end{array}$ & $\mathrm{AME} / \mathrm{DC}$ \\
\hline $\begin{array}{l}\text { Routine cognitive job tasks } \\
\text { (occ.mean) }\end{array}$ & & & & & & & $\begin{array}{l}1.006 \\
(0.50)\end{array}$ & 0.0006 \\
\hline $\begin{array}{l}\text { Routine manual job tasks (occ. } \\
\text { mean) }\end{array}$ & & & & & & & $\begin{array}{l}0.976^{* *} \\
(-2.82)\end{array}$ & -0.003 \\
\hline $\begin{array}{l}\text { Non-routine manual job tasks } \\
\text { (occ.mean) }\end{array}$ & & & & & & & $\begin{array}{l}1.026^{*} \\
(2.02)\end{array}$ & 0.004 \\
\hline $\begin{array}{l}\text { Increase in job skill req. (occ. } \\
\text { mean) }\end{array}$ & & & & & & & $\begin{array}{l}1.061^{* *} \\
(2.75)\end{array}$ & 0.006 \\
\hline Intraclass-correlation (ICC) & 0.511 & & 0.111 & & 0.334 & & 0.094 & \\
\hline Log-likelihood & -4740.2 & & -5921.1 & & -4193.7 & & -4176.0 & \\
\hline
\end{tabular}

Models with job characteristics additionally control for supervisor status, firm size and employment status. t-values (robust standard errors) in parentheses

Sample excludes workers aged 15-24 and 65+and workers without a vocational degree (for detailed sample definition see Sect. 3.1)

$* p \leq 0.05 ; * * p \leq 0.01 ; * * * p \leq 0.001$ (two-sided test)

lower than it is in lower level jobs. In addition, analyses of occupational groups reveal that lower occupational groups (ISCO-88 main groups 8 and 9) are particularly characterized by formal and skill-based overqualification.

To see whether the patterns hold when we control for the other variables, we exploit multivariate models of education and skill mismatch. Specifically, we run random intercept models that allow us to assess how much of the probability of being mismatched results from differences between workers and occupations. Table 4 shows the results from six empty models (intercept-only models) for each category of both mismatching measures where each includes the two other categories as the referent. The intraclass-correlation (ICC) informs about the relative share of the level-2 variance in total variance, i.e., the fraction in the probability of being mismatched maximal resulting from differences between occupations (two-digit ISCO-88). Cleary, there is more variance due to differences between occupations in the probability of educational mismatch than skills mismatch. Thus, broadly speaking, educational mismatch is more strongly linked to occupations, while the risk of skill mismatch in large parts only varies by worker characteristics ${ }^{19}$. Approximately $23 \%$ of the differences in the risk of overeducation and approximately $8 \%$ of the differences in the risk of overskilling are due to occupational heterogeneity. This suggests that with respect to mismatching, occupation or job-related explanations might reasonably complement worker- or human capital-based approaches.

Against the background that, empirically, the incidence rates of overeducation and overskilling are above underqualification and underskilling, we restrict our attention to the determinants of educational and skill-based overquali-

\footnotetext{
${ }^{19}$ The ICC for undereducation (but not for the other mismatching categories) is much lower when those without a vocational qualification are considered.
}

fication. For both dependent variables, we extend the intercept-only models by different sets of variables (Tables 5 and 6). First, we include a variety of socio-demographic variables and variables reflecting worker human capital (models 1). In this study, female workers have higher odds of being formally overeducated $(+11.3 \%)$, whereas (as for overskilling) having children and a migration background do not additionally attract significant coefficients in the pooled sample. As a separate model for males reveals, males who did not learn German as their first language on average have a $6.8 \%$ higher probability of overeducation. Similarily, an employment gap is positively related to the risk of overeducation in the pooled and the male sample.

Therefore, to identify evidence of the occupational mobility hypothesis within these human capital models, we also include age cohorts. In contrast to the assumption that mismatching is just a temporary phenomenon and part of a career mobility strategy of labor market entrants, our results reveal that younger workers do not have a higher probability of being overeducated ${ }^{20}$. With specific human capital (task experience) and health reflecting productivity, we test the human capital compensation (heterogeneous ability) assumption, i.e., whether task experience and health have a share in mismatching and, thus, whether overeducated workers are, in fact, less capable in their jobs than are others. The results for both measures seem to support this assumption. Moreover, for a mean level of years of education the risk of overeducation is substantially lower for workers with ISCED 3B qualifications as compared to university graduates. At the same time, the probability decreases with additional years of education.

\footnotetext{
${ }^{20}$ Instead, for female employees aged $35-44$ have a $3.1 \%$ higher probability of overeducation than those of age 24-34. Possibly this signals processes of re-entering the labor market after family related breaks.
} 
Table 6 Random intercept model of overskilling ( $n=14,266)$. (Source: BIBB/BAuA Employment Survey 2006)

\begin{tabular}{|c|c|c|c|c|c|c|c|c|}
\hline & (1)O.R. & $\begin{array}{l}\mathrm{AME} / \\
\mathrm{DC}\end{array}$ & (2)O.R. & $\mathrm{AME} / \mathrm{DC}$ & (3)O.R. & $\begin{array}{l}\text { AME/ } \\
\mathrm{DC}\end{array}$ & (4)O.R. & $\mathrm{AME} / \mathrm{DC}$ \\
\hline \multicolumn{9}{|l|}{ Age cohort (Ref.: 25-34) } \\
\hline $35-44$ & $\begin{array}{l}0.982 \\
(-0.28)\end{array}$ & -0.002 & & & $\begin{array}{l}0.976 \\
(-0.37)\end{array}$ & -0.003 & $\begin{array}{l}0.977 \\
(-0.35)\end{array}$ & -0.003 \\
\hline $45-54$ & $\begin{array}{l}0.703^{* * *} \\
(-4.41)\end{array}$ & -0.039 & & & $\begin{array}{l}0.687^{* * *} \\
(-4.63)\end{array}$ & -0.039 & $\begin{array}{l}0.691^{* * *} \\
(-4.56)\end{array}$ & -0.038 \\
\hline $55-64$ & $\begin{array}{l}0.769^{*} \\
(-2.31)\end{array}$ & -0.030 & & & $\begin{array}{l}0.745^{*} \\
(-2.55)\end{array}$ & -0.031 & $\begin{array}{l}0.750^{*} \\
(-2.49)\end{array}$ & -0.030 \\
\hline \multicolumn{9}{|l|}{ ISCED (Ref.: 5A, univers. deg.) } \\
\hline $\begin{array}{l}\text { 3B (vocational education and training } \\
\text { qual.) }\end{array}$ & $\begin{array}{l}0.868 \\
(-1.39)\end{array}$ & -0.016 & & & $\begin{array}{l}0.818 \\
(-1.94)\end{array}$ & -0.022 & $\begin{array}{l}0.823 \\
(-1.88)\end{array}$ & -0.021 \\
\hline $\begin{array}{l}\text { 5B (Master craftsmen, technicians, trade/ } \\
\text { technical school qual.) }\end{array}$ & $\begin{array}{l}1.033 \\
(0.28)\end{array}$ & 0.004 & & & $\begin{array}{l}1.079 \\
(0.63)\end{array}$ & 0.009 & $\begin{array}{l}1.081 \\
(0.65)\end{array}$ & 0.009 \\
\hline Virtual education (yrs.) & $\begin{array}{l}1.001 \\
(0.08)\end{array}$ & 0.0002 & & & $\begin{array}{l}1.024 \\
(1.32)\end{array}$ & 0.003 & $\begin{array}{l}1.028 \\
(1.53)\end{array}$ & 0.003 \\
\hline Employment gap & $\begin{array}{l}1.080 \\
(1.41)\end{array}$ & 0.009 & & & $\begin{array}{l}1.007 \\
(0.12)\end{array}$ & 0.001 & $\begin{array}{l}1.004 \\
(0.08)\end{array}$ & 0.001 \\
\hline Task experience (yrs.) & $\begin{array}{l}0.977^{* * *} \\
(-5.43)\end{array}$ & -0.003 & & & $\begin{array}{l}0.980^{* * *} \\
(-4.67)\end{array}$ & -0.002 & $\begin{array}{l}0.980^{* * *} \\
(-4.67)\end{array}$ & -0.002 \\
\hline \multicolumn{9}{|l|}{ Health (Ref.: $1=$ Very bad) } \\
\hline 2 & $\begin{array}{l}0.872 \\
(-0.65)\end{array}$ & -0.019 & & & $\begin{array}{l}0.889 \\
(-0.55)\end{array}$ & -0.015 & $\begin{array}{l}0.886 \\
(-0.57)\end{array}$ & -0.015 \\
\hline 3 & $\begin{array}{l}0.705 \\
(-1.78)\end{array}$ & -0.045 & & & $\begin{array}{l}0.718 \\
(-1.66)\end{array}$ & -0.039 & $\begin{array}{l}0.716 \\
(-1.68)\end{array}$ & -0.039 \\
\hline 4 & $\begin{array}{l}0.677 \\
(-1.95)\end{array}$ & -0.049 & & & $\begin{array}{l}0.697 \\
(-1.77)\end{array}$ & -0.043 & $\begin{array}{l}0.696 \\
(-1.78)\end{array}$ & -0.042 \\
\hline $5=$ Excellent & $\begin{array}{l}0.739 \\
(-1.46)\end{array}$ & -0.039 & & & $\begin{array}{l}0.768 \\
(-1.25)\end{array}$ & -0.032 & $\begin{array}{l}0.768 \\
(-1.25)\end{array}$ & -0.032 \\
\hline Female & $\begin{array}{l}0.978 \\
(-0.37)\end{array}$ & -0.003 & & & $\begin{array}{l}0.855^{*} \\
(-2.35)\end{array}$ & -0.017 & $\begin{array}{l}0.885 \\
(-1.83)\end{array}$ & -0.013 \\
\hline Kid(s) living in the household & $\begin{array}{l}0.975 \\
(-0.42)\end{array}$ & -0.003 & & & $\begin{array}{l}0.948 \\
(-0.85)\end{array}$ & -0.006 & $\begin{array}{l}0.947 \\
(-0.87)\end{array}$ & -0.006 \\
\hline German not learnt as a first language & $\begin{array}{l}1.074 \\
(0.62)\end{array}$ & 0.008 & & & $\begin{array}{l}1.017 \\
(0.15)\end{array}$ & 0.002 & $\begin{array}{l}1.018 \\
(0.15)\end{array}$ & 0.002 \\
\hline Married (Ref.: unmarried, divorced) & $\begin{array}{l}0.829^{* *} \\
(-3.14)\end{array}$ & -0.022 & & & $\begin{array}{l}0.827^{* *} \\
(-3.14)\end{array}$ & -0.021 & $\begin{array}{l}0.824^{* *} \\
(-3.21)\end{array}$ & -0.021 \\
\hline $\begin{array}{l}\text { Residence in East Germany (Ref.: West } \\
\text { Germany) }\end{array}$ & $\begin{array}{l}0.766^{* * *} \\
(-3.83)\end{array}$ & -0.029 & & & $\begin{array}{l}0.736^{* * *} \\
(-4.33)\end{array}$ & -0.031 & $\begin{array}{l}0.732^{* * *} \\
(-4.41)\end{array}$ & -0.031 \\
\hline Non-routine analytic job tasks & & & $\begin{array}{l}0.995^{* * *} \\
(-3.42)\end{array}$ & -0.0005 & $\begin{array}{l}0.993^{* * *} \\
(-4.76)\end{array}$ & -0.0007 & $\begin{array}{l}0.994^{* * *} \\
(-4.11)\end{array}$ & -0.0006 \\
\hline Non-routine interactive tasks & & & $\begin{array}{l}0.999 \\
(-0.67)\end{array}$ & -0.0001 & $\begin{array}{l}0.999 \\
(-0.86)\end{array}$ & -0.0001 & $\begin{array}{l}0.999 \\
(-0.50)\end{array}$ & -0.0001 \\
\hline Routine cognitive job tasks & & & $\begin{array}{l}1.002^{*} \\
(2.09)\end{array}$ & 0.0002 & $\begin{array}{l}1.002^{*} \\
(2.00)\end{array}$ & 0.0002 & $\begin{array}{l}1.002 \\
(1.76)\end{array}$ & 0.0002 \\
\hline Routine manual job tasks & & & $\begin{array}{l}1.002 \\
(1.25)\end{array}$ & 0.0002 & $\begin{array}{l}1.001 \\
(0.96)\end{array}$ & 0.0001 & $\begin{array}{l}1.001 \\
(0.93)\end{array}$ & 0.0001 \\
\hline Non-routine manual job tasks & & & $\begin{array}{l}1.000 \\
(0.05)\end{array}$ & 0.0000 & $\begin{array}{l}1.001 \\
(0.76)\end{array}$ & 0.0001 & $\begin{array}{l}1.001 \\
(0.94)\end{array}$ & 0.0001 \\
\hline Increase in job skill req. & & & $\begin{array}{l}0.681^{* * *} \\
(-7.17)\end{array}$ & -0.042 & $\begin{array}{l}0.693^{* * *} \\
(-6.76)\end{array}$ & -0.040 & $\begin{array}{l}0.694^{* * *} \\
(-6.72)\end{array}$ & -0.039 \\
\hline Shift work & & & $\begin{array}{l}1.255^{* * *} \\
(3.48)\end{array}$ & 0.026 & $\begin{array}{l}1.262^{* * *} \\
(3.51)\end{array}$ & 0.026 & $\begin{array}{l}1.290^{* * *} \\
(3.86)\end{array}$ & 0.028 \\
\hline Part-time job & & & $\begin{array}{l}1.176^{*} \\
(2.54)\end{array}$ & 0.018 & $\begin{array}{l}1.280^{* * *} \\
(3.42)\end{array}$ & 0.028 & $\begin{array}{l}1.292^{* * *} \\
(3.54)\end{array}$ & 0.029 \\
\hline N.-r. analytic job tasks (occ. mean) & & & & & & & $\begin{array}{l}0.986 \\
(-1.95)\end{array}$ & -0.0015 \\
\hline N.-r. interactive job tasks (occ. mean) & & & & & & & $\begin{array}{l}0.996 \\
(-0.74)\end{array}$ & -0.0005 \\
\hline
\end{tabular}


Table 6 (continued)

\begin{tabular}{|c|c|c|c|c|c|c|c|c|}
\hline & (1)O.R. & $\begin{array}{l}\text { AME/ } \\
\text { DC }\end{array}$ & (2)O.R. & AME/DC & (3)O.R. & $\begin{array}{l}\text { AME/ } \\
\text { DC }\end{array}$ & (4)O.R. & $\mathrm{AME} / \mathrm{DC}$ \\
\hline Routine cognitive job tasks (occ. mean) & & & & & & & $\begin{array}{l}0.998 \\
(-0.38)\end{array}$ & -0.0002 \\
\hline Routine manual job tasks (occ. mean) & & & & & & & $\begin{array}{l}0.995 \\
(-1.64)\end{array}$ & -0.0005 \\
\hline Non-routine manual job tasks (occ. mean) & & & & & & & $\begin{array}{l}0.994 \\
(-1.29)\end{array}$ & -0.0006 \\
\hline Increase in job skill req. (occ. mean) & & & & & & & $\begin{array}{l}0.996 \\
(-0.48)\end{array}$ & -0.0004 \\
\hline Intraclass-correlation (ICC) & 0.090 & & 0.033 & & 0.038 & & 0.006 & \\
\hline Log-likelihood & -5262.6 & & -5265.9 & & -5177.4 & & -5160.7 & \\
\hline
\end{tabular}

Models with job characteristics additionally control for supervisor status, firm size and employment status. t-values (robust standard errors) in parentheses

Sample excludes workers aged 15-24 and 65+and workers without a vocational degree (for detailed sample definition see Sect. 3.1)

$* p \leq 0.05 ; * * p \leq 0.01 ; * * * p \leq 0.001$ (two-sided test)

The relationships between the socio-demographic and human capital variables and overeducation do not hold for the overskilling models (Table 6). First, the risk of feeling under-challenged by job skill requirements does not differ between ISCED groups, males and females, migrants and natives (but for male migrants it is $+5.2 \%$ ), and workers with or without an employment gap. Moreover, being underchallenged by the skill requirements of the job is statistically significantly lower for East German residents $(-2.9 \%)$, married workers $(-2.2 \%)$ and workers aged $45-54$ as well as 55-64 compared with workers of age 25-34. As found in other studies (Hartog 2000), these results support the occupational mobility argument. While results for task experience are consistent with the human capital compensation hypothesis (experienced workers have lower risks of overskilling), controlling for other human capital measures, health differences do not matter for overskilling (though z-values are at the edge of statistical significance, especially in the female sample).

Models 2-4 demonstrate that, more so than human capital variables, job characteristics play a role in differences in mismatching categories. First, the more the job is characterized by high-skill, non-routine analytic tasks and increases in skill requirements over the last 2 years, the lower the risk of both, overeducation and overskilling. This could mean that jobs held by overeducated workers have higher skill requirements than can be observed by educational levels, a postulation that favors the job heterogeneity assumption. The risk of overeducation or overskilling is also reduced by routine manual tasks, which is consistent with the assumption that these middle-skilled routine jobs better protect against overqualification because most of these occupations are trained in the German VET system and have clearly defined skill requirements. In the assignment models, we suggested that overeducation might result from a decrease in middling jobs such that formerly adequately matched workers were bumped down in the labor market and thus became overeducated. Generally, this is an assumption about trends which is hard to test with cross-sectional data. However, consistent with this assumption cognitive routine tasks and non-routine manual tasks increase the risk of overeducation but not overskilling (model 4). Finally, with some plausibility from labor market rigidities assumptions, job characteristics such as part-time or shift work are positively related to overeducation and overskilling (the latter, however, is not significant for females). Accordingly, we conclude that some overeducated workers might have chosen a less demanding job because it was the only job available given their time resources.

When both sets of variables are included in one model (model 3), there are no substantial changes in any of the human capital or job-related measures. From this, we conclude that both causes of heterogeneity have their independent share in the variance of overeducation, thereby strengthening support of the job heterogeneity hypothesis. Model 4 additionally includes the job skill requirements of the occupation. Again, the magnitudes of all human capital and job variables are only slightly reduced, if at all. Over and above the partial effects from worker and job characteristics, the skill content of occupations, i.e., the typical skill requirements of occupations, do affect the risk of overeducation. Independent of the workers' job task requirements, being in an occupation that is characterized by high levels of analytic and interactive tasks and routine manual tasks is related to lower risks of overeducation. Actually, the risk is substantially higher the more the occupation relies on nonroutine manual tasks. Except for analytic and manual routine tasks for female workers (odds ratio $<1$ ), the occupational skill requirements do not affect the risk of overskilling.

Overall, first, the multivariate results stress that, to some extent, overeducation and overskilling are distinct phenomena in Germany. Some decisive covariates have opposite 
Table 7 Random intercept model of log hourly wages $(n=14,266)$. (Source: BIBB/BAuA Employment Survey 2006)

\begin{tabular}{|c|c|c|c|c|c|c|}
\hline & $(1)$ & $(2)$ & (3) & (4) & $(5)$ & (6) \\
\hline RE: 3B & $\begin{array}{l}0.410^{* * *} \\
(11.65)\end{array}$ & & & & & \\
\hline RE: 5B & $\begin{array}{l}0.543^{* * *} \\
(14.42)\end{array}$ & & & & & \\
\hline RE: $5 \mathrm{~A}$ & $\begin{array}{l}0.683^{* * *} \\
(18.10)\end{array}$ & & & & & \\
\hline OE: $3 \mathrm{~B}$ & $\begin{array}{l}0.165^{* * *} \\
(4.48)\end{array}$ & & & & & \\
\hline OE: 5B & $\begin{array}{l}0.058^{* * *} \\
(3.45)\end{array}$ & & & & & \\
\hline OE: $5 \mathrm{~A}$ & $\begin{array}{l}0.032^{*} \\
(2.15)\end{array}$ & & & & & \\
\hline UE: 3B & $\begin{array}{l}-0.036^{*} \\
(-2.22)\end{array}$ & & & & & \\
\hline UE: 5B & $\begin{array}{l}-0.061 \\
(-1.54)\end{array}$ & & & & & \\
\hline Overeducated & & $\begin{array}{l}-0.229^{* * *} \\
(-24.71)\end{array}$ & $\begin{array}{l}-0.226^{* * *} \\
(-24.21)\end{array}$ & $\begin{array}{l}-0.209^{* * *} \\
(-22.71)\end{array}$ & $\begin{array}{l}-0.160^{* * *} \\
(-17.59)\end{array}$ & $\begin{array}{l}-0.158^{* * *} \\
(-17.45)\end{array}$ \\
\hline Undereducated & & $\begin{array}{l}0.139^{* * *} \\
(10.12)\end{array}$ & $\begin{array}{l}0.140^{* * *} \\
(10.15)\end{array}$ & $\begin{array}{l}0.136^{* * *} \\
(10.08)\end{array}$ & $\begin{array}{l}0.091^{* * *} \\
(7.00)\end{array}$ & $\begin{array}{l}0.089^{* * *} \\
(6.86)\end{array}$ \\
\hline Overskilled & & & $\begin{array}{l}-0.069^{* * *} \\
(-4.29)\end{array}$ & $\begin{array}{l}-0.061^{* * *} \\
(-3.86)\end{array}$ & $\begin{array}{l}-0.052^{* * *} \\
(-3.45)\end{array}$ & $\begin{array}{l}-0.052^{* * *} \\
(-3.44)\end{array}$ \\
\hline Underskilled & & & $\begin{array}{l}-0.033^{* * *} \\
(-3.58)\end{array}$ & $\begin{array}{l}-0.0247^{* *} \\
(-2.69)\end{array}$ & $\begin{array}{l}-0.017^{*} \\
(-1.99)\end{array}$ & $\begin{array}{l}-0.0171 \\
(-1.95)\end{array}$ \\
\hline \multicolumn{7}{|l|}{ ISCED (Ref.: 5A, univers. deg.) } \\
\hline 3B (vocational education and training) & & $\begin{array}{l}-0.260^{* * *} \\
(-19.98)\end{array}$ & $\begin{array}{l}-0.260^{* * *} \\
(-19.93)\end{array}$ & $\begin{array}{l}-0.250^{* * *} \\
(-19.45)\end{array}$ & $\begin{array}{l}-0.200^{* * *} \\
(-16.05)\end{array}$ & $\begin{array}{l}-0.198^{* * *} \\
(-15.89)\end{array}$ \\
\hline $\begin{array}{l}\text { 5B (Master craftsmen, technicians, trade/technical school } \\
\text { qual.) }\end{array}$ & & $\begin{array}{l}-0.077^{* * *} \\
(-5.30)\end{array}$ & $\begin{array}{l}-0.078^{* * *} \\
(-5.34)\end{array}$ & $\begin{array}{l}-0.074^{* * *} \\
(-5.18)\end{array}$ & $\begin{array}{l}-0.089^{* * *} \\
(-6.49)\end{array}$ & $\begin{array}{l}-0.088^{* * *} \\
(-6.41)\end{array}$ \\
\hline Female & $\begin{array}{l}-0.139^{* * *} \\
(-19.03)\end{array}$ & $\begin{array}{l}-0.140^{* * *} \\
(-19.01)\end{array}$ & $\begin{array}{l}-0.141^{* * *} \\
(-19.05)\end{array}$ & $\begin{array}{l}-0.107^{* * *} \\
(-14.01)\end{array}$ & $\begin{array}{l}-0.100^{* * *} \\
(-13.54)\end{array}$ & $\begin{array}{l}-0.101^{* * *} \\
(-13.60)\end{array}$ \\
\hline Kid(s) living in the household & $\begin{array}{l}0.001 \\
(0.20)\end{array}$ & $\begin{array}{l}0.003 \\
(0.41)\end{array}$ & $\begin{array}{l}0.003 \\
(0.40)\end{array}$ & $\begin{array}{l}0.019^{* *} \\
(2.59)\end{array}$ & $\begin{array}{l}0.017^{*} \\
(2.46)\end{array}$ & $\begin{array}{l}0.017^{*} \\
(2.47)\end{array}$ \\
\hline German not learnt as a first language & $\begin{array}{l}-0.029^{*} \\
(-1.99)\end{array}$ & $\begin{array}{l}-0.038^{*} \\
(-2.57)\end{array}$ & $\begin{array}{l}-0.035^{*} \\
(-2.35)\end{array}$ & $\begin{array}{l}-0.041^{* *} \\
(-2.80)\end{array}$ & $\begin{array}{l}-0.041^{* *} \\
(-2.95)\end{array}$ & $\begin{array}{l}-0.041^{* *} \\
(-2.93)\end{array}$ \\
\hline Married (Ref.: unmarried, divorced) & $\begin{array}{l}0.020^{* *} \\
(2.91)\end{array}$ & $\begin{array}{l}-0.024^{* * *} \\
(3.14)\end{array}$ & $\begin{array}{l}0.023^{* *} \\
(3.23)\end{array}$ & $\begin{array}{l}0.027^{* * *} \\
(3.87)\end{array}$ & $\begin{array}{l}0.025^{* * *} \\
(3.76)\end{array}$ & $\begin{array}{l}0.025^{* * *} \\
(3.78)\end{array}$ \\
\hline Residence in East Germany (Ref.: West Germany) & $\begin{array}{l}-0.250^{* * *} \\
(-32.26)\end{array}$ & $\begin{array}{l}0.0256^{* * *} \\
(-32.60)\end{array}$ & $\begin{array}{l}-0.0258^{* * *} \\
(-32.82)\end{array}$ & $\begin{array}{l}-0.262^{* * *} \\
(-33.65)\end{array}$ & $\begin{array}{l}-0.235^{* * *} \\
(-31.27)\end{array}$ & $\begin{array}{l}-0.235^{* * *} \\
(-31.30)\end{array}$ \\
\hline Virtual education (yrs.) & $\begin{array}{l}0.017^{* * *} \\
(7.90)\end{array}$ & $\begin{array}{l}0.016^{* * *} \\
(7.41)\end{array}$ & $\begin{array}{l}0.016^{* * *} \\
(7.37)\end{array}$ & $\begin{array}{l}0.017^{* * *} \\
(8.06)\end{array}$ & $\begin{array}{l}0.012^{* * *} \\
(5.53)\end{array}$ & $\begin{array}{l}0.011^{* * *} \\
(5.47)\end{array}$ \\
\hline Labor market experience (yrs.) & $\begin{array}{l}0.007^{* * *} \\
(10.16)\end{array}$ & $\begin{array}{l}0.009^{* * *} \\
(14.09)\end{array}$ & $\begin{array}{l}0.009^{* * *} \\
(13.99)\end{array}$ & $\begin{array}{l}0.006^{* * *} \\
(9.43)\end{array}$ & $\begin{array}{l}0.006^{* * *} \\
(8.91)\end{array}$ & $\begin{array}{l}0.006^{* * *} \\
(8.93)\end{array}$ \\
\hline Labor market experience (yrs. $)^{2} / 100$ & $\begin{array}{l}-0.039^{* * *} \\
(-11.02)\end{array}$ & $\begin{array}{l}-0.0040^{* * *} \\
(-11.25)\end{array}$ & $\begin{array}{l}-0.040^{* * *} \\
(-11.19)\end{array}$ & $\begin{array}{l}-0.037^{* * *} \\
(-10.44)\end{array}$ & $\begin{array}{l}-0.031^{* * *} \\
(-9.35)\end{array}$ & $\begin{array}{l}-0.031^{* * *} \\
(-9.35)\end{array}$ \\
\hline Employment gap & $\begin{array}{l}-0.047^{* * *} \\
(-7.16)\end{array}$ & $\begin{array}{l}-0.057^{* * *} \\
(-8.69)\end{array}$ & $\begin{array}{l}-0.057^{* * *} \\
(-8.66)\end{array}$ & $\begin{array}{l}-0.035^{* * *} \\
(-5.27)\end{array}$ & $\begin{array}{l}-0.023^{* * *} \\
(-3.64)\end{array}$ & $\begin{array}{l}-0.023^{* * *} \\
(-3.61)\end{array}$ \\
\hline Task experience (yrs.) & $\begin{array}{l}0.007^{* * *} \\
(15.09)\end{array}$ & & & $\begin{array}{l}0.007^{* * *} \\
(15.11)\end{array}$ & $\begin{array}{l}0.006^{* * *} \\
(14.01)\end{array}$ & $\begin{array}{l}0.006^{* * *} \\
(14.03)\end{array}$ \\
\hline \multicolumn{7}{|l|}{ Health (Ref.: $1=$ Very bad) } \\
\hline 2 & $\begin{array}{l}0.016 \\
(0.56)\end{array}$ & & & $\begin{array}{l}0.011 \\
(0.40)\end{array}$ & $\begin{array}{l}0.003 \\
(0.12)\end{array}$ & $\begin{array}{l}0.003 \\
(0.13)\end{array}$ \\
\hline 3 & $\begin{array}{l}0.064^{*} \\
(2.43)\end{array}$ & & & $\begin{array}{l}0.057^{*} \\
(2.18)\end{array}$ & $\begin{array}{l}0.049^{*} \\
(1.97)\end{array}$ & $\begin{array}{l}0.049^{*} \\
(1.97)\end{array}$ \\
\hline 4 & $\begin{array}{l}0.084^{* *} \\
(3.17)\end{array}$ & & & $\begin{array}{l}0.079^{* *} \\
(2.98)\end{array}$ & $\begin{array}{l}0.060^{*} \\
(2.36)\end{array}$ & $\begin{array}{l}0.060^{*} \\
(2.36)\end{array}$ \\
\hline $5=$ Excellent & $\begin{array}{l}0.076^{* *} \\
(2.75)\end{array}$ & & & $\begin{array}{l}0.072^{* *} \\
(2.65)\end{array}$ & $\begin{array}{l}0.051 \\
(1.95)\end{array}$ & $\begin{array}{l}0.051 \\
(1.94)\end{array}$ \\
\hline
\end{tabular}


Table 7 (continued)

\begin{tabular}{|c|c|c|c|c|c|c|}
\hline & $(1)$ & $(2)$ & (3) & $(4)$ & $(5)$ & $(6)$ \\
\hline Shift work & & & & $\begin{array}{l}0.032^{* * *} \\
(3.93)\end{array}$ & $\begin{array}{l}0.012 \\
(1.44)\end{array}$ & $\begin{array}{l}0.013 \\
(1.59)\end{array}$ \\
\hline Part-time job & & & & $\begin{array}{l}-0.120^{* * *} \\
(-14.01)\end{array}$ & $\begin{array}{l}-0.085^{* * *} \\
(-10.21)\end{array}$ & $\begin{array}{l}-0.085^{* * *} \\
(-10.29)\end{array}$ \\
\hline Non-routine analytic job tasks & & & & & $\begin{array}{l}0.002^{* * *} \\
(11.71)\end{array}$ & $\begin{array}{l}0.002^{* * *} \\
(11.54)\end{array}$ \\
\hline Non-routine interactive tasks & & & & & $\begin{array}{l}0.001^{* * *} \\
(8.36)\end{array}$ & $\begin{array}{l}0.001^{* * *} \\
(8.22)\end{array}$ \\
\hline Routine cognitive job tasks & & & & & $\begin{array}{l}-0.001^{* * *} \\
(-7.94)\end{array}$ & $\begin{array}{l}-0.001^{* * *} \\
(-7.82)\end{array}$ \\
\hline Routine manual job tasks & & & & & $\begin{array}{l}-0.000 \\
(-1.39)\end{array}$ & $\begin{array}{l}-0.000 \\
(-1.39)\end{array}$ \\
\hline Non-routine manual job tasks & & & & & $\begin{array}{l}-0.001^{* * *} \\
(-6.33)\end{array}$ & $\begin{array}{l}-0.001^{* * *} \\
(-6.32)\end{array}$ \\
\hline Increase in job skill requirements & & & & & $\begin{array}{l}0.015^{*} \\
(2.56)\end{array}$ & $\begin{array}{l}0.016^{* *} \\
(2.58)\end{array}$ \\
\hline Non-routine analytic job tasks (occ. mean) & & & & & & $\begin{array}{l}0.002 \\
(1.05)\end{array}$ \\
\hline Non-routine interactive tasks (occ. mean) & & & & & & $\begin{array}{l}0.003 \\
(1.90)\end{array}$ \\
\hline Routine cognitive job tasks (occ. mean) & & & & & & $\begin{array}{l}-0.003^{*} \\
(-2.21)\end{array}$ \\
\hline Routine manual job tasks (occ. mean) & & & & & & $\begin{array}{l}0.00 \\
(1.26)\end{array}$ \\
\hline Non-routine manual job tasks (occ. mean) & & & & & & $\begin{array}{l}-0.00 \\
(-1.86)\end{array}$ \\
\hline Increase in job skill requirements (occ. mean) & & & & & & $\begin{array}{l}0.000 \\
(0.18)\end{array}$ \\
\hline Constant & $\begin{array}{l}2.420^{* * *} \\
(54.28)\end{array}$ & $\begin{array}{l}3.072^{* * *} \\
(84.27)\end{array}$ & $\begin{array}{l}3.079^{* * *} \\
(81.05)\end{array}$ & $\begin{array}{l}2.977^{* * *} \\
(68.11)\end{array}$ & $\begin{array}{l}2.921^{* * *} \\
(77.51)\end{array}$ & $\begin{array}{l}2.765^{* * *} \\
(26.92)\end{array}$ \\
\hline Intraclass-correlation (ICC) & 0.155 & 0.168 & 0.170 & 0.162 & 0.090 & 0.027 \\
\hline $\mathrm{R}^{2}$ occupation-level & 0.713 & 0.668 & 0.672 & 0.697 & 0.860 & 0.961 \\
\hline $\mathrm{R}^{2}$ worker-level & 0.247 & 0.221 & 0.223 & 0.249 & 0.320 & 0.320 \\
\hline $\mathrm{R}^{2}$ total (weighted by ICC) & 0.319 & 0.297 & 0.299 & 0.321 & 0.369 & 0.337 \\
\hline Log-likelihood & -5594.6 & -5834.5 & -5820.0 & -5580.8 & -4860.2 & -4846.5 \\
\hline
\end{tabular}

All models include age cohort. Models with job characteristics additionally control for economic sector, supervisor status, firm size and employment status. t-values (robust standard errors) in parentheses

Sample excludes workers aged 15-24 and 65+and workers without a vocational degree (for detailed sample definition see Sect. 3.1)

${ }^{*} p \leq 0.05 ; * * \leq 0.01 ; * * * p \leq 0.001$ (two-sided test)

effects on educational- and skill-based overqualification, indicating that those who are overeducated are not necessarily those who are overskilled, and vice versa. Second, the models indicate that over and above worker heterogeneity, job heterogeneity has an independent share in explaining overqualification. In addition to the regression coefficients, this is also reflected in the fit statistics. This especially applies for overeducation, where the error variance is strongly reduced when job heterogeneity is considered.

4.2 Wage penalties from mismatching and job heterogeneity

From the human capital compensation hypothesis, mismatching is largely due to unobserved worker heterogene- ity, i.e., overeducated (undereducated) workers are assumed to be less (more) able than other workers with the same education. Alternatively, observed mismatching would be rather a short-term phenomenon and thus would disappear with occupational mobility. In contrast, in assignment models, it is assumed that skill requirements and thus wages are strongly determined by the (characteristics of the) job, not by the human capital of workers (alone). To further investigate the validity of these hypotheses, we examine wage penalties of mismatching using random coefficient models (Table 7).

The empty model estimates a mean log hourly wage of 2.68 (approximately $15 €$ ). About $32 \%$ of the total variance in wages results from differences between occupations, and thus, $68 \%$ is due to differences at the worker level. In model 1 , to test whether the basic ORU pattern is also valid for 
Germany, we introduce the decomposed ORU measures of educational mismatching for each vocational degree and several worker related variables. In fact, we observe that the ORU pattern holds for Germany even when controlling for several human capital and socio-demographic variables. The overeducation coefficients are significantly positive, while the undereducation coefficients are negative $^{21}$. Thus, overeducated (undereducated) workers of each qualification level earn more (less) than those with required levels of education in the same type of jobs, but less (more) than correctly matched workers with the same amount of education. Moreover, the absolute value of returns for each qualification group is higher for overeducation than it is for undereducation. Together, the ORU model explains approximately $71 \%$ of the wage differences between occupations and approximately $25 \%$ of the wage differences between workers. Thus, nearly three quarters of the differences at the occupation level is due to the different composition of workers within occupations (sorting effect).

Second, we run a set of models with regressors for educational (model 2) and skill-based mismatching (model 3). As in the ORU model, model 2 includes standard human capital and socio-demographic variables. As we cannot observe wage growth with our data, our strategy to assess the validity of the occupational mobility hypothesis is to see whether there are mismatching penalties when controlling for age cohorts and labor market experiences. Results show that, on average, compared with workers with the same education, overeducated workers earn approximately $22.9 \%$ less than matched workers, and undereducated workers earn $13.9 \%$ more than workers with jobs that require lower qualifications. Thus, it is concluded that there are substantial wage penalties from mismatching in Germany when several human capital variables are considered.

As in Green and McIntosh (2007), in model 3, we introduce over- and underskilling to see whether the coefficient for overeducation is reduced. However, the reason that the overeducated earn less does not seem to be that they are not using their skills and abilities to the same extent than matched workers with the same education. On the contrary, we find that these skill mismatching variables leave the educational mismatching variables almost unaffected. Over- and undereducated workers earn approximately $22.6 \%$ less and $14 \%$ more, respectively, than correctly matched workers, when controlling for the extent of skill under- and overutilization.

To see whether the over- and undereducated earn less (more) because they are less (more) able than matched workers, in model 4, we additionally include specific human capital (task experience) and health, two measures for (usually

\footnotetext{
${ }^{21}$ As reported in other studies on under-qualification in general, the coefficients for undereducated workers with a German 'Meister' or technical degree are not significantly different from zero.
}

unobserved) ability differences between workers. Though both variables significantly vary with wages in the expected way, against the heterogeneous ability hypothesis, the partial wage effects from over- and undereducation do not change significantly. Moreover, model 4 reveals that introducing additional worker-level variables, (i.e., part-time job $-12.0 \%$, shift work $+3.1 \%$ ) does not alter the pattern.

Model 5 includes job-related variables of the skill content of jobs, employment status, and firm size (the latter two are not printed). If jobs held by the over- or undereducated would be more skill demanding than could be observed by educational level, while holding constant skill utilization, wage penalties from mismatching should be strongly reduced when we add better measures for the skills content of jobs. In fact, the effects from educational mismatching do not dissolve but significantly decline by nearly 5 percentage points each when jobs' tasks are included. Model 5 , which includes job-related variables, is a far superior fit, and it strongly reduces error variance at both the occupational level and the worker level.

Model 6 extends model 5 by incorporating certain occupation level variables. We tested whether the skill profiles of occupations have significant effects on wages, over and above the effects of the skill profiles of workers' jobs. First, in addition to the wage-increasing analytic and interactive task effect and the wage-decreasing effects of routine and non-routine manual tasks at the worker-level (job effects), the more the occupation is characterized by routine cognitive tasks, the lower is the worker's income. Thus, having a job with a higher level of interactive tasks might be devalued by being positioned in an occupation intensive in cognitive routine tasks. Second, it is noted that even with the level-2 covariates, the basic patterns in wage penalties, from educational and skill-based mismatching, are largely unaffected. This, again, fosters the assumption that, to a certain extent, mismatching is a real phenomenon in the German labor market.

\section{Conclusions}

This paper provides actual and precise information on the incidence rates and wage penalties of educational match and skill utilization in Germany. Our analyses are based on the large-scale BIBB/BAuA Employment Survey 2006, which offers rich information on workers' human capital and the skill requirements of their jobs. First, we demonstrate that, at present, as in other industrialized countries, mismatching is a relevant phenomenon in the German labor market. Depending on the definition of mismatching, up to $40 \%$ of the German labor force is mismatched with regards to either the educational or skill requirements of their jobs, or both. As in 
other countries, in Germany, the incidence of overqualification $(24.7 \%)$ clearly outweighs the incidence of under-qualification (10.1\%). Among overqualified workers, the largest group is overeducated workers (13.6\%). Approximately $8 \%$ of all workers are under-challenged by the skill requirements of their jobs, but only $4.3 \%$ are overeducated and overskilled. Equally, the incidence of under-qualification is highest from a credential perspective (approximately $8.4 \%$ ), whereas only $3.3 \%$ claim to be underskilled but not undereducated. With respect to all mismatching categories, having education and skills below the required level, is the most uncommon mismatching phenomenon in Germany $(0.6 \%)$. Thus, workers in Germany can be over- or underqualified in terms of formal qualifications, even though their skills or abilities are perceived to be appropriate for the jobs for which they have been hired. Furthermore, there are workers who are perfectly matched with respect to their education, yet they feel underor overchallenged by the skills requirements of their jobs. Random intercept models with worker, job, and occupation characteristics reveal that beyond worker characteristics, i.e., human capital compensation (heterogeneous ability) and career mobility rationalities, job characteristics help to explain mismatching and its real or apparent wage penalties. Our results suggest that, to some extent, mismatching is a real phenomenon in the German labor market.

Overall, this paper stresses the merits of the job requirement approach. With respect to the study of skill demand in general, research on mismatching greatly benefits from subjective measures on the skill content of jobs. Based on the results of job tasks, it would be worthwhile to study the link between polarization and mismatching using over time data. The Employment Survey is a repeated cross-sectional survey that allows for replicating some of the analyses presented above for data collections from 1979, 1985/86, 1991/92, 1998/99 and 2012 (Rohrbach-Schmidt and Tiemann 2011). Ideally, however, to test for the occupational mobility hypothesis and to separate cohort from age effects, our analyses should be validated with panel data. A further extension would be to distinguish between subjects studied, testing whether overeducated workers are equally as able as matched workers, though they have degrees in subjects that are in less demand in the labor market (e.g., Green and McIntosh 2007). The analyses could be further extended by including specific occupation-level variables, e.g., indicating the occupation's current labor market situation (unemployment rates, regional distribution).

\section{Kurzfassung}

Der Beitrag untersucht anhand der BIBB/BAuA-Erwerbstätigenbefragung 2006 das Ausmaß von Fehlqualifizierungen und damit verbundene Einkommenseinbußen in
Deutschland. Die fehlende Passung der Qualifikationen und Kenntnisse von Erwerbstätigen mit den Anforderungen der Arbeitsplätze ist mit negativen Konsequenzen für die Erwerbstätigen (etwa in Form von geringerer Arbeitszufriedenheit und geringen Löhnen), sowie für die betroffenen Firmen und damit auch die Gesamtwirtschaft verbunden. Zudem zeigen Studien, dass das Ausmaß von Überqualifizierung in einigen Ländern, darunter Deutschland, in den letzten Dekaden zugenommen hat (Korpi und Tahlin 2009; Green 2006, für Deutschland Rohrbach-Schmidt und Tiemann 2011). Weiterhin geben Arbeiten zum Tätigkeitsansatz Anlass zu einer Untersuchung von Fehlqualifizierung, insofern, als dass hiermit die Bedeutung der Tätigkeitsinhalte von Arbeitsplätzen bzw. Berufen für das Verständnis von Qualifikationsanforderungen und Löhnen verbunden ist (Autor et al. 2003).

Deutschland bietet vor diesem Hintergrund einen besonders guten Anwendungsfall für die Untersuchung von Fehlqualifizierungen. Zum einen ist das deutsche Bildungs- und Beschäftigungssystem aufgrund einer starken beruflichen Orientierung durch eine enge Verzahnung von Qualifikationen und Beschäftigung und damit einem eher geringem Ausmaß von Fehlqualifikationen gekennzeichnet (Büchel und Witte 1997; Daly et al. 2000, für eine ländervergleichende Analyse siehe die Studie von Verheast und Van der Velden 2013). Zum anderen liegen mit den Daten der BIBB/BAuA-Befragung 2006 Forschungsdaten für 20.000 Erwerbstätige vor, die insbesondere den Erwerb und die Verwertung von beruflichen Qualifikationen zum Inhalt haben sowie Informationen zu den Tätigkeitsinhalten der Arbeitsplätze beinhalten. Die Daten enthalten neben Informationen zur Passung des Qualifikationsniveaus der Erwerbstätigen mit den formalen Qualifikationsanforderungen des Arbeitsplatzes auch Angaben dazu, inwieweit die fachlichen Kenntnisse und Fähigkeiten der Erwerbstätigen mit den fachlichen Anforderungen am Arbeitsplatz übereinstimmen. Wir machen uns diese Angaben zunutze und untersuchen, a) inwieweit beide Formen der Passung zusammenhängen, b) welche Eigenschaften der Erwerbstätigen und welche Merkmale der Arbeitsplätze bzw. der Berufe im Zusammenhang mit formaler und fähigkeitsbezogener Überqualifizierung stehen und c) welche Einkommenseinbußen mit qualifikatorischem Mismatching unter Berücksichtigung der Unterschiede in der Ausnutzung der fachlichen Kenntnisse und Fähigkeiten der Erwerbstätigen verbunden sind. Die Untersuchung basiert dabei auf in Deutschland lebenden Kernerwerbstätigen, d.h. Erwerbstätige, die einer bezahlten Arbeit von mindestens zehn Wochenstunden nachgehen.

Zunächst zeigen einfache deskriptive Auswertungen der beiden Passungsmaße, dass unter den 25 bis 64 Jahre alten Erwerbstätigen in Deutschland rund 71 Prozent im Hinblick auf ihre formalen Qualifikationen und 82 Prozent im Hin- 
blick auf ihre fachlichen Kenntnisse und Fähigkeiten passend beschäftigt sind. Überqualifizierungen sind bei beiden Passungsarten dabei das empirisch bedeutsamere Phänomen: $18,6 \%$ sind formal über- und $10,1 \%$ formal unterqualifiziert beschäftigt, $13,1 \%$ sind im Hinblick auf ihre fachlichen Kenntnisse und Fähigkeiten über- und nur 4,6\% unterqualifiziert beschäftigt. Im Hinblick auf a) zeigt sich, dass der Zusammenhang zwischen beiden Passungsvariablen eher gering ist, d.h. qualifikatorisches und fähigkeitsbezogenes Mismatching treten nicht immer gemeinsam auf. Demnach sind unter den formal fehlqualifizierten Beschäftigten in Deutschland zahlreiche Erwerbstätige, deren fachliche Kenntnisse und Fähigkeiten den Anforderungen des Arbeitsplatzes entsprechen. Gleichzeitig haben nicht alle passend qualifizierten Beschäftigten die fachlichen Kenntnisse und Fähigkeiten, die auf ihrem jeweiligen Arbeitsplatz gefordert sind. Multivariate Random-Interceptmodelle für Erwerbstätige mit mindestens einer Berufsausbildung als höchstem Bildungsabschluss zeigen mit Bezug zu b), dass das Risiko von formaler Überqualifizierung stärker als bei fähigkeitsbezogener Überqualifizierung von Unterschieden zwischen Berufen herrührt und dass neben dem Humankapital und anderen Merkmalen der Individuen arbeitsplatzbezogene Eigenschaften in substantiellem Zusammenhang mit Fehlqualifizierung stehen. Insbesondere sinkt die Wahrscheinlichkeit für eine nicht den qualifikatorischen bzw. den fachlichen Kenntnissen und Fähigkeiten gemäßen Beschäftigung mit der Bedeutung von analytischen Tätigkeiten am Arbeitsplatz und ist geringer auf Arbeitsplätzen, deren fachliche Anforderungen in den letzten zwei Jahren gestiegen sind. Diese Befunde sind vereinbar mit der Annahme, dass Arbeitsplätze von überqualifiziert Beschäftigten durch höhere Anforderungen gekennzeichnet sind, als dass dies durch das formale Qualifikationsniveau beobachtbar ist. Entsprechend der aus den Überlegungen zur Arbeitskräftepolarisierung abgeleiteten Annahme einer höheren Überqualifizierung am unteren Ende der Qualifikationsverteilung zeigt sich, dass die Wahrscheinlichkeit von formaler Überqualifizierung auf Arbeitsplätzen bzw. in Berufen mit einer hohen Bedeutung von nicht-routine manuellen Tätigkeiten gekennzeichnet ist. Random-Interceptmodelle des logarithmierten Stundenlohns erbringen mit Bezug zu c) schließlich, dass Lohneinbußen durch Überqualifizierung auch dann zu beobachten sind, wenn die Passung der fachlichen Kenntnisse und Fähigkeiten und weitere oft unbeobachtete Leistungsmerkmale wie die Tätigkeitserfahrung und der Gesundheitszustand berücksichtigt werden. Zudem gehen sie zwar in ihrer Höhe zurück, wenn weitere lohnrelevante Personen- und Arbeitsplatzmerkmale (darunter die Leistungsanforderungen des Arbeitsplatzes) sowie das Tätigkeitsprofil von Berufen berücksichtigt werden, sie bleiben aber dennoch in substantieller Größe bestehen. Die zentralen Befunde des Beitrags zeigen sich dabei sowohl für männliche als auch weiblich Erwerbstätige.

Insgesamt sprechen die Ergebnisse dafür, dass Fehlqualifizierung entgegen humankapitaltheoretischen Ansätzen und gemäß der Annahmen von Job Competition und Assignmenttheorien ein reales Phänomen in Deutschland darstellt. Insbesondere bietet der Tätigkeitsansatz Potential für neue Erkenntnisse zum Thema, die in weiteren Studien vertieft werden müssen. Für das Thema ergibt sich damit insgesamt auch im Hinblick auf die theoretische Fundierung ein weiterer Forschungsbedarf.

Acknowledgement We thank Michael Handel, Francis Green and two anonymous reviewers for helpful discussion and comments.

Open Access This article is distributed under the terms of the Creative Commons Attribution License which permits any use, distribution, and reproduction in any medium, provided the original author(s) and the source are credited.

\section{Appendix}

Table 8 Categorization of task items to ALM task groups for 2006 cross-sectional analysis

\begin{tabular}{llll}
\hline Task group & $\begin{array}{l}\text { Typical level } \\
\text { of qualification }\end{array}$ & $\begin{array}{l}\text { Assumed labor } \\
\text { market demand }\end{array}$ & $\begin{array}{l}\text { Item in BIBB/ } \\
\text { BauA 2006 }\end{array}$ \\
\hline $\begin{array}{l}\text { Non-routine } \\
\text { cognitive, } \\
\text { analytical }\end{array}$ & High & Increasing & F310, F311, \\
F313, F318 \\
$\begin{array}{l}\text { Non-routine } \\
\text { cognitive, }\end{array}$ & High & Increasing & F312, F314 \\
$\begin{array}{l}\text { interactive } \\
\text { Routine } \\
\text { cognitive }\end{array}$ & Medium & Falling & F307, F308 \\
$\begin{array}{l}\text { Routine } \\
\text { manual }\end{array}$ & Medium/low & Falling & F303, F304, \\
Non-routine & Low & Constant/increasing & F315, F316, F317
\end{tabular}

manual

Alignments are initially based on a principal component analysis solution (for the study of task change in Germany over the period 1979 to 2006 see Rohrbach-Schmidt and Tiemann 2011). The variables of the first of the four factors are subsequently aligned to the analytical and interactive sub-categories, respectively. Items F309 and F319a are not included in the index because of their high loadings on more than one factor. The question posed in 2006 was 'how often do the following activities (random order) occur at work frequently, sometimes, never'. The index is the worker's sum of point values (2006: frequently $=1$, sometimes $=0.5$, never $=0$; divided by the total number of activities in the respective task group 
F303 Manufacturing, producing of products and goods

F304 Measuring, testing, quality control

F305 Operating, controlling machines, plants, technical processes

F306 Repairing, maintenance

F307 Buying, providing, selling

F308 Transporting, stocking, posting

F309 Promoting, marketing, public relations (not included)

F310 Organizing, planning/preparing work processes

F311 Researching, developing, designing

F312 Training, teaching, tutoring, educating

F313 Gathering information, investigating, documenting

F314 Consulting, advising

F315 Entertaining, accommodating, preparing food

F316 Nursing, caring, healing

F317 Securing, protecting, guarding, monitoring, traffic

F318 Working with computers

F319a Cleaning, waste disposal, recycling (not included)

\section{References}

Acemoglu, D.: Technical change, inequality, and the labor market. J. Econ. Lit. 40(1), 7-72 (2002)

Alda, H., Rohrbach-Schmidt, D.: "Imputation fehlender Werte für die Einkommensvariable in der BIBB/BAuA-Erwerbstätigenbefragung 2006". BIBB-FDZ Daten- und Methodenberichte, 1/2011. BIBB, Bonn (2011)

Allen, J., and van der Velden, Rolf: Educational mismatches versus skill mismatches. Effects on wages, job satisfaction, and on-thejob search. Oxford Econ. Pap. 53(3), 434-452 (2001)

Antonczyk, D., DeLeire, T., Fitzenberger, B.: "Polarization and Rising Wage Inequality: Comparing the U.S. and Germany" IZA Discussion Paper Series, No. 4842, Bonn (2010)

Autor, D., Dorn, D.: This job is "getting old": measuring changes in job opportunities using occupational age structure. American Economic Review, 99(2): 45-51 (2009)

Autor, D.H., Handel, M.J.: Putting tasks to the test. Human capital, job tasks and wages. Journal of Labor Economics 31(2), 59-96 (2013)

Autor, D.H., Levy, F., Murnane, R.J.: The skill content of recent technological change: An empirical exploration. Quart. J. Econ. 3(4), 1279-1333 (2003)

Autor, D.H., Katz, L.F., Kearney, M.S.: "The polarization of the US labor market", American Economic Review, 96(2), 189-194 (2006)

Autor, D.H., Katz, L.F., Kearney, M.S.: Trends in U. S. wage inequality. Revising the revisionists. Rev. Econ. Stat. 90(2), 300-323 (2008)

Bauer, T.K.: Educational mismatch and wages. A panel analysis. Econ. Educ. Rev. 21(3), 221-229 (2002)

Büchel, F., Battu, H.: The theory of differential overqualification. Does it work? Scott. J. Political Econ. 50(1), 1-16 (2003)

Büchel, F., Mertens, A.: Overeducation, undereducation, and the theory of career mobility. Appl. Econ. 36(8), 803-816 (2004)

Büchel, F., van Ham, M.: Overeducation, regional labour markets and spatial flexibility. J. Urban Econ. 424(53), 482-493 (2003)

Büchel, F., Witte, J.C.: "The incidence and consequences of overeducation among young workers in the United States and Germany. A comparative panel analysis", Proceedings of the 1996s International Conference of the German Socio-Economic Panel Study Users, 66(1), 32-40 (1997)
Card, D., DiNardo, J.E.: "Skill biased technological change and rising wage inequality. Some problems and puzzles", Journal of Labor Economics 20(4), 733-783 (2002)

Carnoy, M.: "Vocational Education: Is There a "Best" Model in the New Global Economy?" Unpublished Keynote Speech. EHB Switzerland, Interdisciplinary Congress on Research in Vocational Education and Training (2009)

Chevalier, A.: Measuring over-education. Economica. 70(279), 509$531(2003)$

Daly, M.C., Büchel, F., Duncan, G.J.: Premiums and penalties for surplus and deficit education. Evidence from the United States and Germany. Econ. Educ. Rev. 19(2), 169-178 (2000)

Dolton, P., Vignoles, A.: The incidence and effects of overeducation in the UK graduate labour market. Econ. Educ. Rev. 19(2), 179-198 (2000)

Duncan, G.J., Hoffman, S.D.: The incidence and wage effects of overeducation. Econ. Educ. Rev. 1(1), 75-86 (1981)

Dustmann, C., Schoenberg, U.: Why does the German apprenticeship system work? Skill formation. 2008, 85-108 (2008)

Dustmann, C., Ludsteck, J., Schoenberg, U.: Revisiting the German Wage structure. Quart. J. Econ. 114(2), 843-882 (2009)

Frenette, M.: The overqualified Canadian graduate: the role of academic program in the incidence, persistence, and economic returns to overqualification. Econ. Educ. Rev. 23, 29-45 (2004)

Frey, C., Osborne, M.A.: The Future of Employment: How Susceptible are Jobs to Computerization? University of Oxford (2013)

Goos, M., Manning, A.: Lousy and lovely jobs. The rising polarization of work in Britain. Rev. Econ. Stat. 89(1), 118-133 (2007)

Goos, M., Manning, A., Salomons, A.: "Recent changes in the European employment structure: the roles of technology and globalization", Open Access publications from Katholieke Universiteit Leuven, Katholieke Universiteit Leuven (2009)

Green, F.: Demanding Work. The Paradox of Job Quality in the Affluent Economy. Princeton University Press, Princeton (2006)

Green, F.: "Employee Involvement, Technology and Evolution in Job Skills: A Task-Based Analysis." Industrial \& Labor Relations Review 65. pp. 35-66 (2012)

Green, F., McIntosh, S.: Is there a genuine under-utilization of skills amongst the overeducated? Appl. Aconomics. 39, 427-439 (2007)

Green, F., Zhu, Y.: Overqualification, job dissatisfaction, and increasing dispersion in the returns to graduate education. Oxford Econ. Pap. 62(2), 740-763 (2010)

Groot, W. and Maassen van den Brink, Henriette: Overeducation in the labor market. A meta-analysis. Econ. Educ. Rev. 19(2), 149-158 (2000)

Hadjar, A., Becker, R. (eds.): Expected and Unexpected Consequences of the Educational Expansion in Europe and the US. Haupt, Bern (2009)

Hall, A., Siefer, A., Tiemann, M.: BIBB/BAuA Employment Survey of the Working Population on Qualification and Working Conditions in Germany 2012. suf_4.0; Research Data Center at BIBB (ed.); GESIS Cologne (data access); Bonn: Federal Institute for Vocational Education and Training. doi:10.7803/501.12.1.1.40 (2015)

Hall, A., Tiemann, M.: BIBB/BAuA Employment Survey of the Working Population on Qualification and Working Conditions in Germany 2006: suf_1.0; Research Data Center at BIBB (ed.); GESIS Cologne (data access). Federal Institute for Vocational Education and Training, Bonn (2006). doi:10.4232/1.11072 (2009)

Handel, M.J.: "Skills Mismatch in the Labour Market", Annual Review of Sociology, 29 (2003)

Handel, M.J.: "Measuring Job Content: Skills, Technology, and Management Practices". Institute for Research on Poverty. Discussion paper 1357-08 (2008)

Hartog, J.: Over-education and earnings. where are we, where should we go? Econ. Educ. Rev. 19(2), 131-147 (2000) 
Hillmert, S.: When traditions change and virtues become obstacles. Skill formation in Britain and Germany. Skill formation. 2008, 50-81 (2008)

Hox, J.: Multilevel analysis. Techniques and applications. Erlbaum, Mahwah (2002)

Kalleberg, A.L. (ed.): Organizations in America. Analyzing their structures and human resource practices. Sage Publications, Thousand Oaks (1996)

Konsortium Bildungsberichterstattung: Bildung in Deutschland. Ein indikatorengestützter Bericht mit einer Analyse zu Bildung und Migration. W. Bertelsmann Verlag, Bielefeld (2006)

Korpi, T., Tåhlin, M.: Educational mismatch, wages, and wage growth. Overeducation in Sweden; 1974-2000. Lab. Econ. 16(2), 183-193 (2009)

Lazear, E.P.: A jobs-based analysis of labor markets. Am. Econ. Rev. 85(2), 260-265 (1995)

Leuven, E., Oosterbeek, H.: Overeducation and Mismatch in the Labor Market. Handbook of the Economics of Education 4 (2011): 283-326.

Lutz, B., Grünert, H.: Beruflichkeit, das Risiko von Arbeitsmarkt-Mismatch und offene Fragen. In: Der gesellschaftliche Umgang mit Ungewissheit - Berufe und Professionen als Beispiel. Mitteilungen des SFB 580 Nr. 13, S. 59-69 (2003)

McGuinness, S.: Overeducation in the labour market. J. Econ. Surveys. 20(3), 387-418 (2006)

Morris, M., Western, B.: Inequality in Earnings at the Close of the Twentieth Century. Annu. Rev. Sociol. 25, 623-657 (1999)

Müller, W., Brauns, H., Steinmann, S.: Expansion und Erträge tertiärer Bildung in Deutschland, Frankreich und Vereinigten Königreich. Berl. J. Soziol. 12(1), 37-62 (2002)

OECD (ed.): Education at a Glance. OECD, Paris (2007)

Oesch, D., Rodriguez, J.: Upgrading or polarization? Occupational change in Britain, Germany, Spain and Switzerland, 1990-2008, Socio-Economic Review 9(3), 503-531 (2011)

Quintini, G.: Over-Qualified or Under-Skilled. A review of existing literature. OECD Social, Employment and Migration Papers No. 121 (2011)

Rabe-Hesketh, S., Skrondal, A.: Multilevel and longitudinal modeling using stata (2. ed. ed.). Stata Press, College Station (2008)

Raudenbush, S.W., Bryk, A.S.: Hierarchical linear models. Applications and data analysis methods (2nd ed ed.). Sage Publ, Thousand Oaks (2002)

Rohrbach-Schmidt, D.: The BIBB/IAB- and BIBB-BAuA Surveys of the Working Population on Qualification and Working Conditions in Germany. BIBB-FDZ Daten- und Methodenberichte Nr. 1/2009. Bonn: BIBB. ISSN 2190-300X (2009)

Rohrbach-Schmidt, D., Tiemann, M.: Mismatching and job tasks in Germany - rising over-qualification through polarization? Empir. Res. Vocat. Educ. Train. 1(3), 39-53 (2011)

Rubb, S.: Overeducation in the labor market. A comment and re-analysis of a meta-analysis. Econ. Educ. Rev. 22(6), 621-629 (2003a)
Rubb, S.: Overeducation: a short or long run phenomenon for individuals? Econ. Educ. Rev. 22(4), 389-394 (2003b)

Sattinger, M.: Assignment models of the distribution of earnings. J. Econ. Lit. 31(2), 831-880 (1993)

Schneider, S.L. (ed.): Applying the ISCED-97 to the German educational qualifications. S. 76-102 in: The International Standard Classification of Education (ISCED-97). An Evaluation of Content and Criterion Validity for 15 European Countries. Mannheimer Zentrum für Euorpäische Sozialforschung (MZES), Mannheim (2008)

Sichermann, N., Galor, O.: A theory of career mobility. J. Polit. Economy. 98(1), 169-192 (1990)

Sørensen, A.B., Kalleberg, A.L.: An outline of a theory of the matching of persons to jobs, pp. 49-74 in: I. E. Berg, Sociological perspectives on labor markets. Academic Press, New York (1981)

Spence, M.A.: Job market signaling. Quart. J. Econ. 87(3), 355-374 (1973)

Spitz-Oener, A.: Technical change, job tasks, and rising educational demands: Looking outside the wage structure. J. Lab. Econ. 24(2), 235-270 (2006)

Statistisches Bundesamt: Bildung und Kultur. Nichtmonetäre hochschulstatistische Kennzahlen 1980-2008 (Reihe 4.3.1 (ed.)). Wiesbaden: Statisches Bundesamt (2009)

Thurow, L.C.: Generating inequality. Basic Books, New York (1975)

Tiemann, M.: Actual changes in the world of work. Development of the division of labor in Germany since 1979. Paper presented at 17th ILERA World Congress 2015, "The Changing World of Work: Implications for Labour and Employment Relations and Social Protection", Cape Town, ZA (2015)

Verhaest, D., Van der Velden, R.: Cross-country differences in graduate overeducation. Eur. Sociol. Rev. 29(3), 642-653 (2013)

Daniela Rohrbach-Schmidt Senior Researcher at the German Federal Institute for Vocational Education and Training (BIBB), Research Data Centre (BIBB-FDZ) since 2008. M.A. in Sociology, University of Duesseldorf, Germany, 2004. Dr. rer. pol. in Sociology, Faculty of Management, Economics and Social Sciences at the University of Cologne, Germany, in 2008. Research Areas: Labor Market Sociology, Sociology of Education, Social Stratification, Quantitative Methods, Cross-National Comparisons.

Michael Tiemann Senior Researcher at the German Federal Institute for Vocational Education and Training (BIBB), Section "Qualification, Occupational Integration, Employment" since 2007. M.A. in Philosophy, University of Leeds, GB, 2000. M.A. in Sociology, University of Duesseldorf, Germany, 2006. Dr. rer. pol. in Sociology, Faculty of Management, Economics and Social Sciences at the University of Cologne, Germany, in 2014. Research Areas: BIBB/BAuA Employment Surveys, Changes in Occupational Contents, Knowledge in Work. 